\title{
Rethinking imperial infrastructure: a bottom-up perspective on the Inca Road
}

\author{
Francisco Garrido \\ Curator, Museo Nacional de Historia Natural, Santiago, Chile \\ Ph.D. in Anthropology, University of Pittsburgh \\ frg10@pitt.edu
}

\begin{abstract}
The Inca road has been the iconic example of imperial infrastructure in the prehispanic Andes. However, scholarly attention to its role in expanding and consolidating the Inca domain has overshadowed analysis of how locals may have appropriated the Inca road for their own private benefit. Based on a full-coverage survey and excavations, this article presents the case of small mining communities along the Inca road and the use they made of it. I argue that they most likely leveraged on emerging imperial infrastructure, in order to expand their existing lapidary and pigment production and exchange in the Atacama desert. The Inca Road may thus have served as an unintended stimuli for local economic activities, since it improved transportation logistics, and served as a linear exchange nexus. I further demonstrate how the Inca Road was, to some extent, appropriated to serve local economic purposes. This provides a unique "bottomup" perspective of how the Inca infrastructure could not be fully controlled by the elites. Thus, the "imperial landscape" created by the Inca Road was more permeable than what the Incas expected and scholars have assumed, despite the physical or ideological coercion elites may have enforced.
\end{abstract}

Key words: Inca road, imperial infrastructure, Atacama desert, prehistoric mining

\section{Introduction}

The famous Qhapaq Ñan or Inca Road is commonly viewed as a "vast network for the acquisition, management, movement, and protection of labor" (Hyslop 1984:247), becoming "the omnipresent symbol of the empire throughout the Andes" (Hyslop 1990:xiii). Despite its major role in consolidating political control for the growing empire, we know little about local and nonimperial uses of the Road in the past. Considering the far-flung multi-ethnic landscape that the road traversed, this article presents evidence to argue that it is very likely that independent individuals used the Inca Road for their private purposes in ways that were unknown to, and unintended by, state authorities. People living in the imperial provinces may have interacted with the Inca Road autonomously, appropriating this infrastructure for themselves, in ways that did not contribute to consolidating the expansion of the empire. Thus, the main argument of this article is that the Atacama Inca Road did not only serve as a highway servicing Inca imperial needs, as in the standard current understanding of the Inca Road's function. Instead, I contend that the Inca Road also served non-state purposes, such as a linear exchange nexus for surrounding local populations.

This view challenges an implicit assumption in many studies of the effects of Inca conquest, where subject households or communities are presented as economically passive. In cases such as the classic Upper Mantaro Valley Project, the Inca conquest effectively produced intensification of production in textile and agriculture of local populations, where previous 
domestic patterns of production remained basically unchanged (D'Altroy 2002a; Earle 2002). Instead, this article provides evidence for other possibilities, where households or small corporate units can act as independent economic agents in their own right, taking advantage of shifts in an overarching economic setting that arise from political conquest (Douglass 2002; Gonlin 2012; Falconer 1995; Hendon 1996; Hirth 2009; Netting 1993; Wilk 1989). These changes, then, are autochthonous or 'grass roots', dictated more by possibilities in local domestic economy than by imperial political economy. Such changes, however, may still be stimulated, or shaped, by the overarching imperial system, perhaps in unanticipated ways. A wealth of studies of households in ancient Mesoamerica document precisely these behaviors (Clark and Blake 1994; Earle and Smith 2012; Feinman and Nicholas 2004; Feinman et al. 1984; Marcus 2006; Smith and Smith 1994; Smith et al. 2003; Hirth 1998, 2010). The lack of interest in entrepreneurial-type household economic change is due chiefly to the long-standing conviction that there was "no market" in the prehispanic Andes (cf. Mayer 2013). In contrast to this classic view of the Inca conquest, new perspectives point to the diversity of household economies in the Inca empire. For example, scholars have shown that the lack of modern market behavior practices in the late prehispanic Andes did not preclude forms of barter at the household level (Gallardo 2013; Murra 1980, 1995; Stanish 2010; Stanish and Coben 2013; Stark and Garraty 2010). Additionally, a few Inca scholars have been willing to recognize "entrepreneurial" activity at the margins of the empire (Martin 2010; Murra 1980, 1995; Salomon 1986; Rostworowski 1989). Consequently, this article's example of small scale mining in the Atacama desert has the heuristic value of showing such local entrepreneurial response to change in economic conditions resulting from the Inca conquest. This can serve as a complementary and alternative interpretation to the traditional top-down labor taxation model. Together, these suggest a different scenario for bottom level provisioning for Inca subjects.

To support this "bottom-up" perspective, I explore the relationship between the Inca Road and a recently discovered, non-Inca but contemporaneous system of mining camps, isolated deep in the Atacama Desert, northern Chile. The core of the archaeological analysis is based on an empirical and contextual assessment of the materials actually moving along a section of the Inca Road. This article examines how non-Inca mining camps oriented to the production of greenstone beads and red pigment production, which had already existed prior to the Late Horizon, took advantage of new opportunities offered by the Inca Road. The data generated on domestic and craft activities, and on local and long distance exchange, contributes to our understanding of the scope of how local people responded to imperial hegemony. Local interaction with the Inca Road may represent "bottom-up" responses to contact with the new institutions and infrastructure of the overarching imperial system. While less prominent than centrally-directed economic enterprises, these responses constitute and significantly shape collective trends of economic strategies at the local household and community levels.

\section{Current view of the Inca Road}

Spread across more than 30,000 kilometers from Colombia to Central Chile, the Inca Road was the most extensive infrastructure for the administration of Inca empire. It consisted of multiple routes that were connected by a series of nodal sites, for the control of traffic and provisioning of food, water, and lodging for official travelers. For Julien (2012:147), the Inca Road was an "important structuring feature of an initial form of imperial administration". Other scholars have observed how it also served to support the army (D'Altroy 1992, 2015; Earle 2009), enabled the management of staple and wealth finance (Jenkins 2001), and facilitated the promotion of state ideology and ritual (Astuhuamán 2004; Castro et al. 2004; Vitry 2007; Stehberg 1995). These examples point to the predominant perspective on the Inca Road, where its relevance is largely 
viewed in terms of the intentions of Inca authorities. This perspective overlooks the actual consequences and effects that the Road may have had over the empire's subordinate subjects in conquered territories.

Hyslop's (1984) landmark monograph remains the interpretive and methodological touchstone for archaeological approaches to the Inca Road system. Subsequent research has extended his point-to-point tracing of segments of the road while producing an inventory of the kinds of features (apachetas), sites (tampu, chaskiwasi), and structures (kallanka, colcas, corrals) along it (Berenguer et al. 2005; Castro et al 2004; INC 2005 - 2009 volumes 1 -8; Stehberg 1995; Vitry 2000). Hyslop's discussion of the variety of traffic on the road was limited to a single paragraph (1984:254), and his emphasis on the Inca Road's use for state-related business continues to inform current scholarship: "Soldiers, porters, and llama caravans were prime users, as were the nobility and other individuals on official duty... Other subjects were allowed to walk along the roads only with permission..." (D'Altroy 2002b:243). But Hyslop himself recognized the importance of investigating other dimensions of road usage, noting that, "there was also an undetermined amount of private traffic...about which little is known" (Hyslop 1984:254). A ubiquitous feature of the Inca Road system is the informal (non-Inca) roadside structures that may or may not be associated with official tambos or tampu. These can be seen in the Hyslop plan of Ranchillos, where over 80 small circular or comma shaped structures occur alongside and behind formal Inca canchas (1984:198). In a survey of the Inca Road from Morohuasi to Salta, Vitry (2000) recorded such structures at 7 of 15 roadside sites, including El Cardonal (with 45 such structures). These structures are sometimes viewed as "overflow" housing for travelers when tambo and other official facilities are full, or as storage spaces to support tambos and similar installations. Archaeologically, however, these buildings have received much less empirical and theoretical attention than formal tambos.

To summarize, most of the archaeological evidence related to local activities or non-Inca infrastructure on the Inca Road has generally been regarded as irrelevant to describing the road's administrative functions. Beyond the description of the primary functions of the road, there has not been specific studies in relation to the effects of the Inca Road on roadside populations and settlements. Such a study can illuminate the nature and extent of changes in local economic patterns and behavior. Despite general assumptions that local and dispersed populations were completely integrated into the Inca empire due to its impressive administrative and organizational capacities, there are still no empirical examples of how the presence of the Inca Road may have affected by local agents and their economic activities, or vice versa.

\subsection{Ethnohistorical narratives about the Inca Road infrastructure and usage}

Ethnohistorical accounts have been highly influential in shaping the current archaeological perspective of the official uses and top-down control of the Inca Road. These tend to emphasize the authority of the Inca rulers and their power to oversee everything under their domains. Guaman Poma de Ayala (1980), Martín de Murúa (2001), and Garcilaso de la Vega (1991) emphasize the presence of imperial infrastructure on the Inca royal roads where lodging posts for state officials and chasqui messengers were ubiquitous across the empire. Royal officials such as the "tocricoc" would have been in charge of the cleanliness and maintenance of the roads. They also mention that the Incas took special care to build roads with a standard width, and locals expressed respect and admiration for them, especially when bridges had to be built.

The imperial ubiquitous lodging posts were evenly spaced out and well-provisioned. These would have kept food, clothes, and weapons ready for the Inca armies that marched across the empire (de la Vega 1991). These posts are also reflected in the hierarchy of "mesones", 
"tambos" and "tambillos" that Poma de Ayala used to describe the official infrastructure present along the imperial roads. Garcilaso explicitly stated that commoners were not permitted to walk on the road, except unless they were sent by the Inca rulers or their local chiefs or curacas (de la Vega 1991:231-232). For these walkers on duty, there were special lodging posts called "corpahuaci", which would have had a different function from the aforementioned tambos. Beyond the organization and grandiosity of the Inca road, the only factor disrupting official traffic - as mentioned by de Ayala and de la Vega - are road thieves or "pomaranra" (de Ayala 1980:291), whose presence produced insecurity and could never be eliminated.

In contrast to the chroniclers who focused on the greatness of the Inca Road, the ones who refer specifically to the Inca Road in the Atacama desert wrote about the great difficulties of the crossing of this region. Gonzalo Fernández de Oviedo narrates the logistical problems of traversing the desert with regards to Diego de Almagro's return expedition from Copiapó to Perú (Fernández de Oviedo 1855). He notes how people had to be divided into small groups for the administration of food and water supplies, and how some horsemen had to be sent in advance for the opening the scarce water wells or "xagueyes" all along the road. A very similar narrative is also given by the chronicler Betanzos (2004), who attributes instead to Tupac Inca Yupanqui the labor of opening these water wells. In another early narrative, the chronicler Gerónimo de Bibar also contributes to understanding the harsh conditions of these expeditions. In his narrative of Pedro de Valdivia's expedition via Copiapó in 1540, he mentions the corpses of people who died during Almagro's trip back to Perú in 1537, which were lying at the many circular structures along the road (Bibar 1966:18-19). These roadside circular structures are interpreted by Bibar as places for protection from cold temperatures and wind at night, though he does not provide much information about nor suggest other possible uses.

In general, the chroniclers who wrote from the Cuzco imperial perspective described the construction of the Inca Road in terms of the greatness of the Inca rulers as a project of civilization and order brought to the Andean world. Non-imperial local uses of the Inca road were not mentioned, except for the disturbance of occasional thieves, as mentioned above. On the other hand, those who mentioned the Inca road in the Atacama desert, mostly remarked on the difficulties of the crossing this arid region, which could only be possible due to this road and associated infrastructure.

\subsection{Comparative perspectives on "imperial" roads}

One of the goals of this paper is to question the idea that imperial roads only served official needs. While that is still the case for the Inca Road, there are several comparative examples that can expand this dominant perspective. Scholars tend to assume that the Inca rulers possessed total political control over populations and infrastructure: "The traditional English meaning (of highway) incorporates the concept of a public road freely open to all passengers. Such was not the case of the Inka roads, which served primarily for travelers on state business" (Hyslop 1984:2). Traditional perspectives of imperial roads generally focused on the interest of elites to expand their domains and sustain their political economy, by moving troops, and improving communication and transportation logistics (Earle 2009). By the same logic, it is often assumed that states may try to control and restrict uses of roads to official purposes, to prevent private individuals from indiscriminately taking advantage of the benefits that roads provide. Nevertheless, there are several examples where local populations have bypassed formal regulations to use such roads for their own private goals.

In the case of the highly exclusive imperial roads in Japan, despite state prohibition of private traffic, the roads were still used by large numbers of private individuals who carried out their 
own commercial activities under the guise of peregrination (Vaporis 2012). In imperial China, by the fourth century BCE, roads primarily served state functions, but powerful families profited from them by setting up private transportation and courier services (Nylan 2012:44). The difficulty of controlling the extent of imperial networks by the authorities can also be seen in the case of the Roman empire, where the enduring popular perception of absolute control by authorities arguably reflects scholars' assumptions than actual facts. As Talbert points out, modern scholars assume a "global cartographic awareness" for granted, although it is very unlikely that the Roman emperors and the imperial elite had conceptualized the entire reach and connectivity of their roads (Talbert 2012:247). The reconstruction of imperial expansion from the point of view of the elites tends to overemphasize the degree of actual control that they had over peripheral territories. Such a view neglects the role of local agencies that also interact and negotiate with the empire in diverse and unpredictable ways.

The role of imperial- and state-built roads in facilitating conquests and domination, or in articulating local peoples to larger economic systems, has been explored in a variety of contexts (Banerjee et al. 2012; Bryceson et al. 2008; Canning and Fay 1993; Kreutzmann 1991; Speidel 1987; Wiseman 1970; Witcher 1998). Recent studies of the anthropology of infrastructure have also recognized the importance of ethnographically considering institutionalized material technologies, including roads. These studies have focused on the role of infrastructure in the consolidation of contemporary state power, while also exploring the complexity of their articulation among local populations, who can eventually subvert or re-signify those devices for their own goals (Amin 2014; Chu 2014; Harvey and Knox 2015; Larkin 2013). Surprisingly, there has been little comparable theoretical work on the famous Inca Road. What sort of small-scale, local enterprises might have developed to take advantage of the Inca Road in pre-hispanic times? And how would these indigenous enterprises differ (in character and goals) from how such activities were organized as part of the Inca imperial system? While there is information on what the Inca rulers did with their roads (or said they did, as reported by early chroniclers such as Garcilaso), next to nothing is known of how local groups may have exploited the imperial infrastructure for their own economic and social purposes. The existence of the road itself could have provided new economic opportunities for local populations. It would have linked them to the Inca world in ways that eluded the nodes of Inca control, ways that were unintended by the Inca Empire. In other words, the nature of roads is never neutral, generating challenges and advantages to multiple social actors (Snead 2012), creating selective but generally unplanned effects on their surroundings (Hassig 1991).

The placement of new roads in urban or rural contexts can strongly influence transformations in the geographical surroundings. These changes can be related to the presence of service areas for travelers, informal markets, development of nearby economic activities, and presence of secondary byways to connect with previously isolated territories. Examples of these can be seen in the case of Roman roads in North Africa that were able to improve land communications between distant centers. These allowed rural settlements to exchange their products in bigger markets, thus inspiring more migrations to urban centers, facilitating tax collection, and promoting "an early and sustained globalization" (Hitchner 2012:232). The great amount of traffic, and the improvements in public safety, the pax romana, contributed to producing a cosmopolitan idea of the Roman Empire, which created the rise of private "tourism" in distant provinces (Foubert and Breeze 2014). In a different example, the construction of new railway lines in North America during the 19th century produced an important change in the production of agriculture commodities, providing cheap transportation and generating more surpluses, in what has been defined as "social saving" (Fogel 1962). In modern studies of roads, it has also been argued that roads can contribute not only to improve the economy but also to create "social inclusion" by connecting isolated communities to larger networks, which possess more 
access to opportunities for development (OECD 2002). In a closer geographical setting, llama caravan studies in Bolivia have shown precisely how long-distance traffic can provide multiple opportunities for low-level household bartering exchange along the route (Nielsen 2000, 2001, 2009, 2013). Considering that the Inca Road was the largest pre-Columbian imperial infrastructure in the Andes, there is enormous potential in exploring the local interaction and appropriation of the road, beyond that of the expansionist logic of the Inca elites. Therefore, this paper will provide an example of how the Inca Road influenced indigenous economic changes on small-scale mining activities, as exemplified in the case of the Atacama desert, northern Chile.

\section{The Inca Road in the Atacama Desert}

In Atacama, constructing the Inca Road faced unique challenges in crossing the driest desert in the world: hundreds of kilometers without sedentary populations, the lack of agricultural potential (except at a few oases), and almost no water sources. The archaeological interpretation of the Inca Road in the desert has followed the same top-down model described in the previous sections. However, due to the lack of water and food needed to support the Inca army and the movement of bulk goods, the Inca Road through the Atacama Desert has been described as having primarily administrative functions, rather than serving economic or military purposes (Hyslop 1984:248, Jenkins 2001). Lynch (1993) has observed that the Inca Road in the Atacama Desert served mainly to connect Inca administrative centers, in ways that were unrelated to local population densities. For Berenguer (2007), the Inca Road interconnected a series of imperial settlements that created local "provinces" independently administered. In a similar way, Incas built a series of stone pyramidal landmarks on the Inca road to demarcate their administrative provinces in Atacama, as part of managing their geopolitical interests (Sanhueza 2004).

In highlighting the economic function of the road, some scholars have suggested that mining exploitation was prevalent in the Atacama Inca road, due to the amount of copper ore fragments and metal artifacts found along the route (Lynch 1993, Lynch 1994-1995, Lynch and Nuñez 1994, Niemeyer and Rivera 1983, Iribarren 1972, Iribarren and Bergholz 1972). At the same time, some Inca sites were located in immediate proximity to these mines, thus suggesting the importance of the road's articulation alongside the Inca state's political economy (Adán 1999; Berenguer 2004, 2007; Berenguer et al. 2005; Berenguer and Caceres 2008, Raffino 1982, Uribe and Adán 2004). The main examples of Inca mining/metallurgic sites with orthogonal architecture on the Inca Road are Cerro Verde in Salado river (Adán 1999; Salazar et al. 2013), and Cerro Colorado in the Alto Loa area (Berenguer 2007; Uribe and Urbina 2009). At both sites there is a clear state emphasis on the use of large public spaces to perform ritualized state reciprocity, where corvèe laborers (mit'a) participated in sponsored feastings, as indicated in the large quantity or aryballos and serving vessels in public spaces.

Central nodes in the Inca Road had great importance for the development of administrative and economic activities. The site of Tarapacá Viejo is an example of a major Inca administrative center, well interconnected by the Inca road to the north and south, and the highlands in the east (Zori and Urbina 2014). Here, the Incas reorganized previous local architecture and centralized metallurgical activities of silver and copper refining for the imperial political economy. The Incas physically separated the different stages of silver metal artifact production, carrying out only the first stage of silver smelting via lead cupellation in Tarapacá Viejo. The refined metals were then transported elsewhere for final processing and artifact manufacture (Zori and Tropper 2010, 2013). In the case of copper production, smelting via the huayra or wind-driven furnace started before the Incas but then this production was centralized, and tin bronze was 
introduced as the preferred alloy for the control of production of Inca prestige goods (Zori et al. 2013).

Additionally, the segment of the Inca Road in the upper Loa river is a representative case of how a newly built road was constructed over previous paths that could have served to supply the nearby Inca mining activities at El Abra and Conchi Viejo. Significantly, these mining activities and sites were also supported by the nearby agricultural production in the Loa River Valley (Berenguer et al. 2005). There are also local agropastoralist sites along the road, such as the homesteads around Santa Barbara, Cerro Colorado, and Bajada del Toro. These have been hypothesized to have provided logistical support for Inca activities, such as supplying food and cargo animals for officials transiting through this segment of the road. However, when scholars have acknowledged the participation of local populations, these have been viewed only in terms of the fulfilment of Inca economic and political goals. Broadly, these studies follow a reciprocal model where local people gave their labor and resources in exchange for state sponsored festivities at administrative sites. In other words, local people are represented simply as laborers for the interest of the Inca Empire.

Despite scholarship privileging the use of the road for official economic and administrative purposes, there is some evidence that mining along the road began and were continuous from pre-Inca times. Lynch's survey to the area of Punta Negra salt marsh led to the discovery of turquoise beads and sea shells at many sites associated with parallel paths that were connected to the main Inca Road. Importantly, these artifacts were associated with both Inca and pre-Inca pottery (Lynch 1993:140). Another case is the turquoise mine of El Salvador, which was exploited from the Late Formative until the Late Horizon (Gonzalez and Westfall 2010; Westfall and Gonzalez 2010; Iribarren and Bergholz 1972). Here, it is clear that most of the mining exploitation was done during Pre-Inca times, although there has not yet been a thorough investigation of its association with the Inca Road.

\section{The unexpected effects of the Inca Road on small-scale mining in Cachiyuyo de Llampos Mountains}

In this section I will present this study's findings aimed at understanding the changes produced or influenced by the Inca Road on nearby local and pre-existing economic activities. Drawing on this data, I argue that these changes are not always due to top-down demands or processes, but also that local agents can find opportunities in the interstitial spaces of the imperial provincial rule. To make this case, this section presents 1) the research methodology, 2) the situation of pre-Inca mining craft activities in the survey area, 3) the local context in Copiapó valley during the Inca arrival, in order to 4) discuss an analysis of the changes that occurred to roadside mining-craft activities during the Late Horizon.

\subsection{Methodology and survey area}

During the year 2014, I conducted a full-coverage pedestrian survey in the mountain formation locally known as Cachiyuyo de Llampos (figure 1). The purpose of this survey was focused on determining the effects of the construction and functioning of the Inca Road on the surrounding mining camps that pre-dated the Inca arrival. Before the Incas, an already fully developed lapidary and pigment mining exploitation system was in place in the Cachiyuyo de Llampos mountains (figure 2). The study of the continuity of small scale household occupations is key to understanding how the Inca Road may have altered the productive conditions of the nearby and contemporary mining camps. On the other hand, investigating the associated roadside 
settlement can clarify if these camps represented more than way stations or temporary camps for travelers along the Inca highway.

Therefore, the fieldwork was focused on investigating the mining settlement system at Cachiyuyo de Llampos mountains, located at about 60 kilometers north from the closest populated valley which is Copiapó. The survey includes the study of all sites, and the determination of the full range of activities carried out at them. The survey area comprises 58 square kilometers, and includes an Inca Road segment of 12 linear kilometers passing only 3 kilometers west from the mountain foothills, plus the Chinchilla ravine where the mining camps are located. These mountains contain vertical hydrothermal magmatic ore deposits of the breccia pipe type (Maksaev et al. 2007), and the main ores exploited there were copper and gold, although the most abundant is the hematite (Segerstrom 1960). In the middle part of Chinchilla ravine there is one small water well carved on the ground that may have supported the consumption of few people before its natural refill. That is the only source of water for dozens of kilometers around. It thus clearly played an important role in the establishment of human mining occupations during prehistoric times.

All the architecture of the identified mining camps was recorded, as well as their activity areas and surface materials. The sites were divided in quadrants no larger than $10 \times 10$ meters, and all their surface artifacts were recorded and counted in situ. Special consideration was given to evidence of craft production and the chronology of the sites was assigned in function to their pottery styles. The survey also recorded all surface materials of the Inca Road and the paths that interconnect the mining camps across the area. This helped to determine the activities and intensity of traffic along these routes.

Besides the pedestrian survey, test pits were dug at sites Tambo Medanoso and Chinchilla 1 $(\mathrm{CH} 1)$ to obtain larger artifact assemblages from the two sites, to reveal stratigraphy, and to obtain samples for AMS radiocarbon dating. Tambo Medanoso was selected as the clear "official" Inca site in the survey area, while $\mathrm{CH} 1$ was selected as the largest non-Inca mining camp contemporaneous with the Inca Road. Excavation at Tambo Medanoso consisted of 6 units, 4 of $1 \times 1.5$ meters and 2 of $1 \times 2$ meters. At CH1 the excavation consisted of 8 units, 7 of $1 \times 1.5$ meters and 1 of $1 \times 2$ meters. Test pits were spread among the different contexts (residential structures, bead production linear structures, open areas, dump, hearths). They were placed in interior and exterior areas, and possible midden deposits (ashy or high surface density loci). Because of the extremely dry environmental conditions, all the surrounding landscape is devoid of agricultural potential, and sedentary populations. These conditions thus contributed to an excellent artifact surface visibility, in order to distinguish the relatively undisturbed surface artifact distributions and activity areas in the prehistoric mining camps.

Due to the lack of vegetation and the distant location of oases, it is unlikely that llama caravans were used regularly for transportation in this region. There is no ethnographic evidence for llama transport in this area of the desert, and the routes across the Andes to the east were more viable for caravan movement during prehispanic times, especially since pasturelands were available at the end of each daily journey. It is thus highly likely that most of the movement in this section of the Inca Road, including mining activities carried out in the area, comprised of pedestrian traffic. 
Survey Area Location

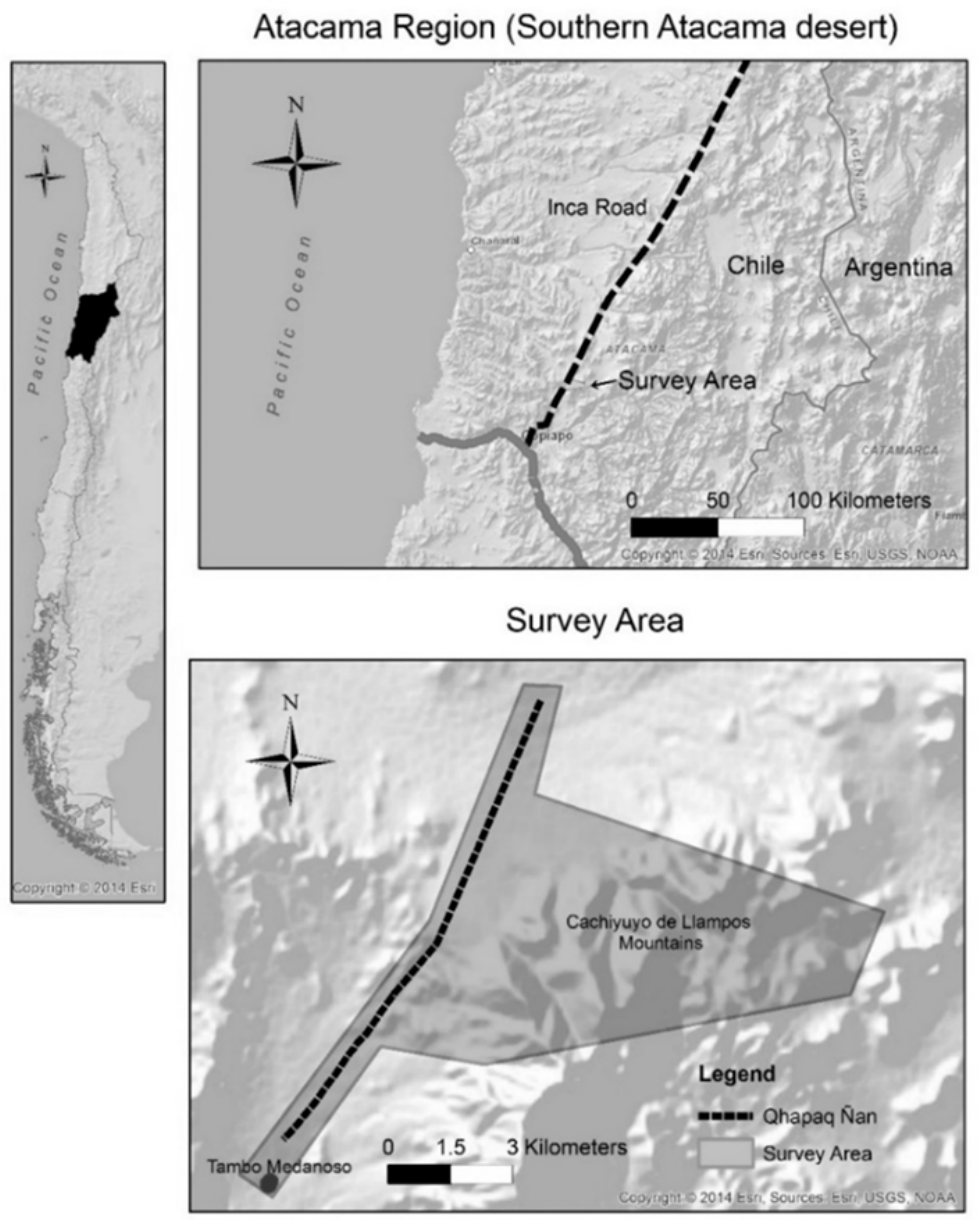

Figure 1. Survey area

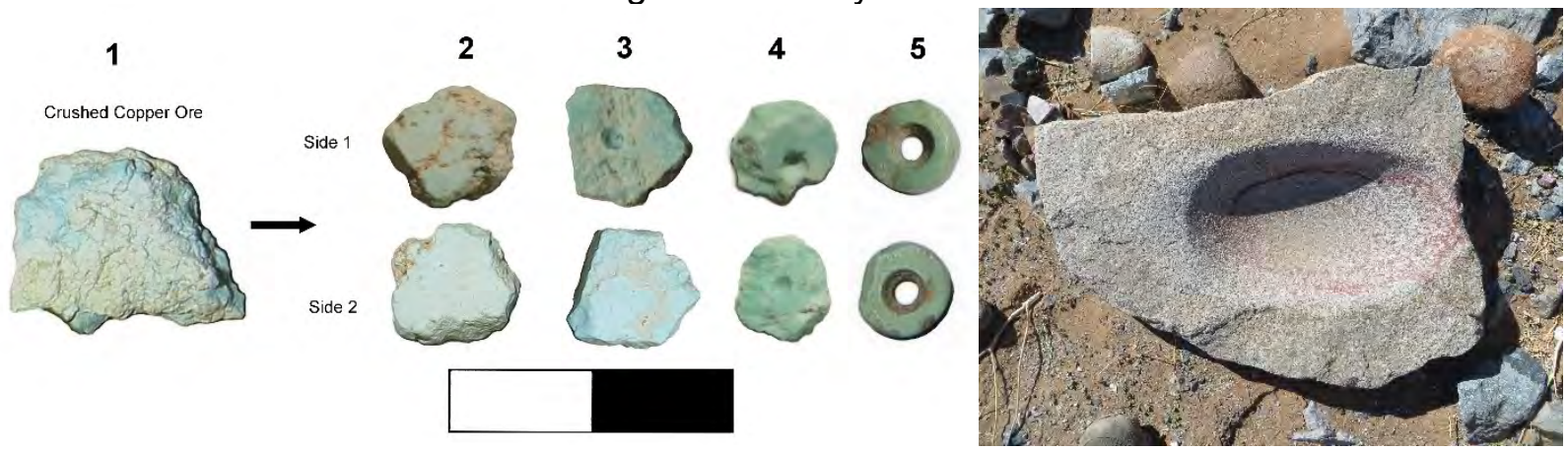

Figure 2. Bead chaîne opératoire and mortar for pigment grinding with residues, representing the craft activities derived from mining at Cachiyuyo de Llampos mountains 


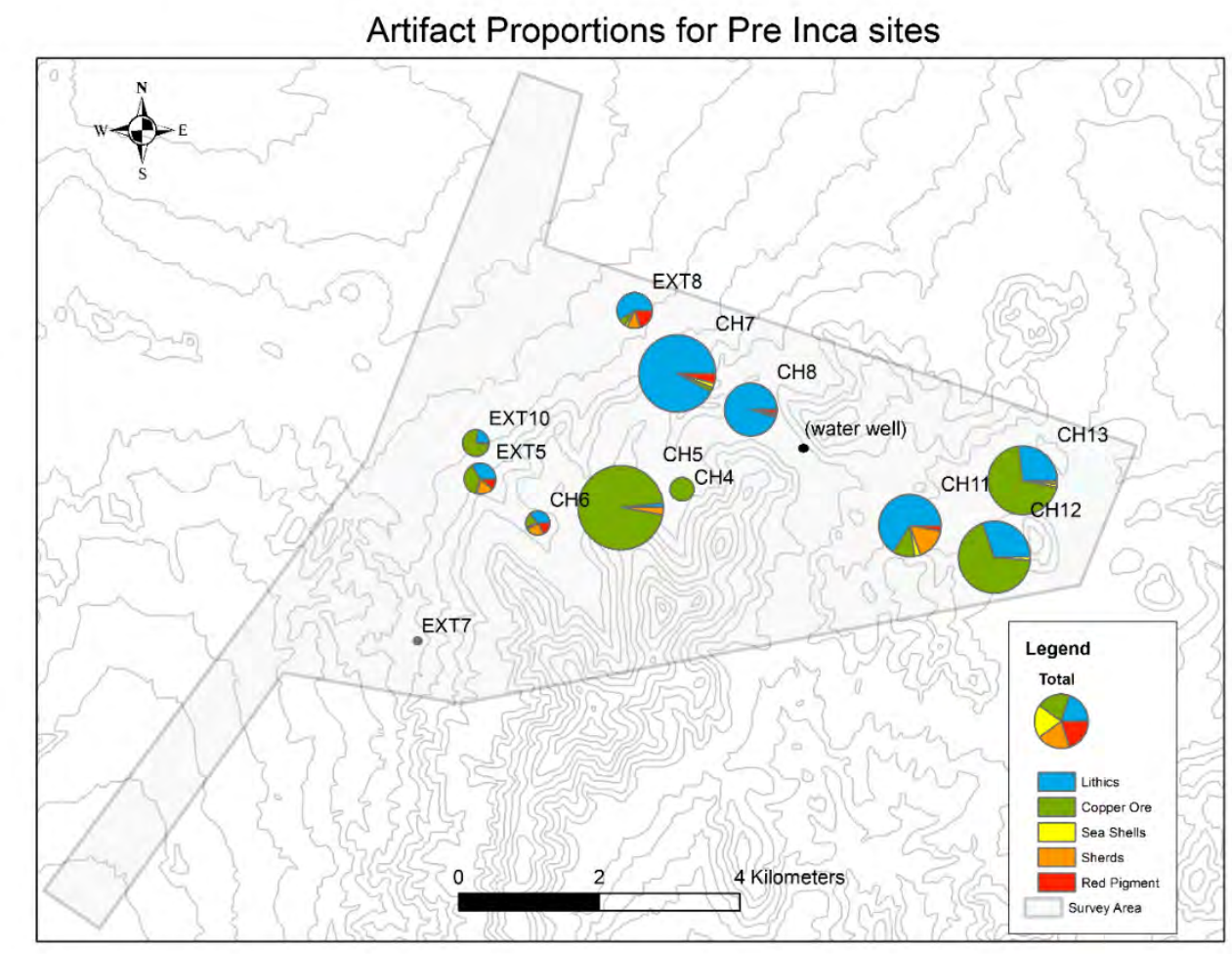

Figure 3. Map of artifact proportion and frequency for Pre Inca periods

I will present the situation of the small scale mining activities in Cachiyuyo de Llampos during pre-Inca times, in order to contextualize and understand the changes that happened once the research area was incorporated to the Inca Empire and the Inca Road was built. This will offer a base for the next sections from which to compare and contrast the locally generated economic changes in the mining camps during the Late Horizon, in order to see how the proximity of the Inca Road may have affected the previous mining and crafting pattern.

The Cachiyuyo de Llampos total coverage survey revealed 13 sites within the mountainous area, and 10 in the exterior western plains, all of them with architecture. From all of them, eleven can be assigned to Pre-Inca times. These were encampments focused on mining and craft production composed of clusters of circular structures built from local available stones, as well as open activity areas for craft working. The main crafts produced at these sites were lapidary beads, red pigment, and lithic items such as projectile points, scrapers, and bifacial knives made by non-local raw materials, and seashell beads (figure 3 ). There is evidence of the exploitation of immediate ore veins and the manufacturing of small flat circular beads of turquoise and malachite, and powdered hematite in grinding stones to elaborate red pigment. The occupation of the area started before the Inca epoch. Most sites have archaeological evidence from as early as the Late Formative/Alfarero Temprano periods ( 300 BC-700AD), related to the Ciénaga Culture from northwestern Argentina, and the local Molle culture from Copiapó Valley. When all Pre-Inca sites are compared on the same scale, their residential structures are clearly similar in size, suggesting that they had a similar number of residents (figure 4). Not all the structures may have had residential functions, and structures smaller than 
2 meters in diameter probably served storage purposes instead. Additionally, most of the sites are composed of two main clusters of structures, which are separated by a few meters. Thus, the modus operandi of mining exploitation in the desert may have favored the work of small itinerant groups, considering both the logistic constraints regarding water and food supply in the desert, and the lack of a large demand of mining products. On the other hand, the site area of these mining camps, including the entire dispersion of their structures and surface materials, is consistently smaller than 2,000 square meters. The maximum number of structures per site including both residential and small storage spaces is 14 , and the media is 8.8 per site. If they were household units, that figure may represent 1 to 2 households, or perhaps small corporate groups consisting of 5-10 people in total.

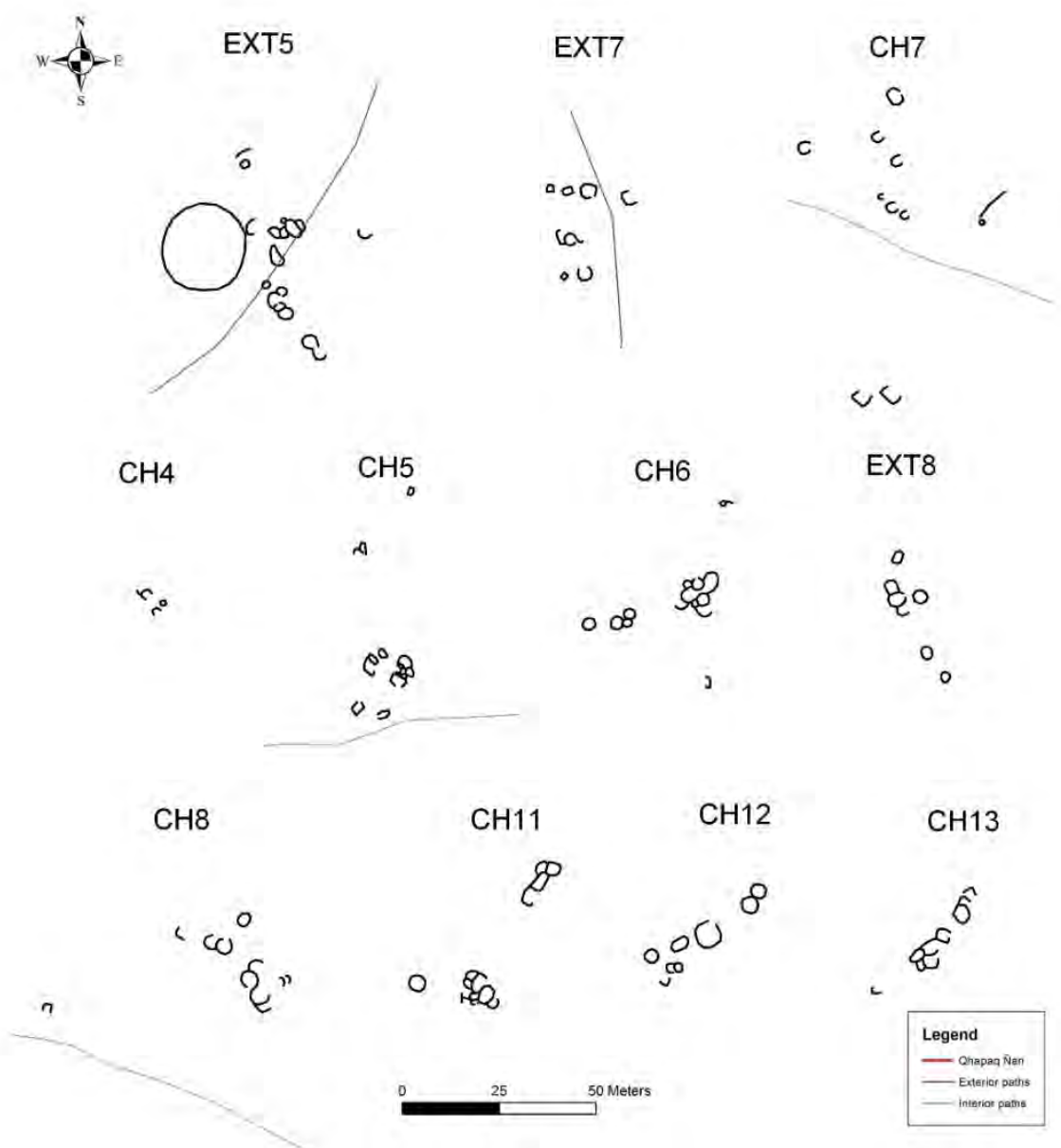

Figure 4. Pre-Inca sites architecture plans

The presence of Pre-Inca mining camps indicates that before the presence of the Inca Road, there was already an autonomous and fully developed mining system with some levels of multicrafting (c.f. Mills 2007; Shimada 2007), although each site specialized in either bead making or lithic artifact manufacture. At that time, there were already stable long-distance connections between the Andes and the coast for the circulation of sea shells and lithic raw materials such as obsidian, although there is no evidence of a formalized route where later the Inca road was built. Miners had to carry all their supplies to the desert during their expeditions, and it is unlikely that they had frequent contact with other people, except for the occasional exchange of sea shells, obsidian, and fine grain flint. They also had to travel all the way to populated places such as Copiapó valley via informal trails, in order to meet the final consumers 
of their products. This scenario would later change with the establishment of the Inca Road next to the former miners' productive territory. During this time, most of the occupation began to concentrate around areas closer to the road.

\subsection{The integration of Copiapó valley to the Inca empire}

The closest valley to the survey area is Copiapó, from where the miners belonged as suggested by their pottery styles. The region was integrated to the Inca empire, establishing their major occupation in the upper part of the valley, focusing on the metallurgical production as evidenced by the presence of the large foundry Viña del Cerro, (Niemeyer 1986, Niemeyer et al. 1993, Castillo 1998). This regional copper smelting complex is a classic Inca production center, with a plaza structure, an ushnu, and 26 smelters. The site is the best example of centralized, large scale, Inca controlled metal production in the region, and as such, embodies a mode of economic activity coexisting with, but very different from, the household level mining, as seen in the sites of Cachiyuyo de Llampos mountains that is the subject of this research. The labor force for the Viña del Cerro facility presumably came from nearby villages of the Copiapó Valley as mit'a labor. The finished products likely left the area along a section of the Inca Road, especially through mountain passes across the Andes, given that most of the Inca administrative sites such as La Puerta, Iglesia Colorada and El Castaño are located in an area of more agricultural resources in the upper part of Copiapó Valley and along tributary rivers to the Copiapó river (Castillo 1998, Niemeyer et al. 1993). That area provides enough pasturelands to support larger llama caravans and that was also the route from which the conquistador Diego de Almagro entered for first time into Copiapó valley in 1536. The Inca Road through the desert provides a shorter and faster connection to the north but could not support a vast amount of traffic due to the logistic constraints of the desert crossing, playing possibly a secondary role during the Inca expansion but an important role for lapidary miners as I will show here.

Inca rule in Copiapó valley was not implemented by the Inca state alone, but in alliance with Diaguita groups. Consequently, it has been suggested that the Inca conquest moved from south to north in the region, from the Elqui valley where the Diaguitas lived (Berenguer 2009; Cornejo 1999, 2001; Uribe 2000). The Copiapó Valley contains Diaguita pottery styles dating to the Inca period, but no pre-Inca Diaguita pottery (Ampuero 1978; Castillo 1998; Cornely 1956; González 2000; Niemeyer et al. 1993). Diaguitas would have administered the area for the Incas, over the local populations that corresponded to small chiefdoms characterized by their particular Copiapó black on red and Punta Brava pottery styles. In relation to lapidary goods, there is no evidence of production or control of these craft products by the Inca in this valley, and they may have served the interest of commoners and intermediate elites. 
4.4 Main changes during the Late Horizon: Mining camp aggregation and multicrafting at Cachiyuyo de Llampos.

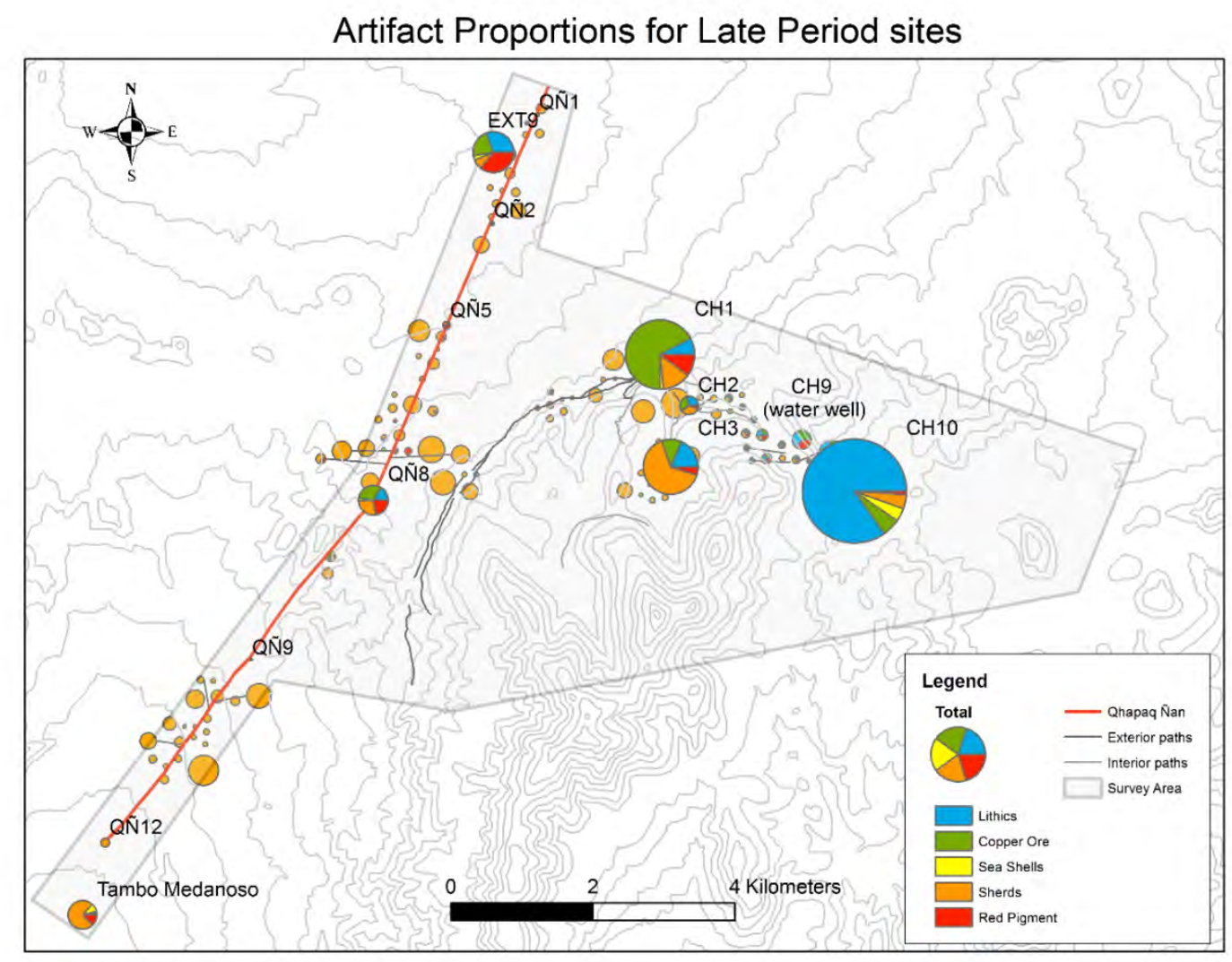

Figure 5. Map of artifact proportion and frequency during the Late Horizon

Following the Inca conquest, Late Horizon mining camps exhibited an internal reorganization and more uniform proportions of artifacts than before (figure 5). These changes were subtle, and largely in degree rather than in kind. My research showed the following shifts in mining patterns: 1) there is a more intensive settlement with longer-term occupation at the largest camps; 2) nucleation, particularly at site $\mathrm{CH} 1$; 3) a preference for camp locations closer to the Inca Road; 4) an increase in red pigment production, and decline in stone tool production; and 5) a decline in inter-site specialization, increasing multicrafting.

The evidence of the shift in the settlement pattern suggests that the Inca Road influence "pulled" the previously dispersed mining camps to its proximity, allowing them to grow larger, and become spatially concentrated. These factors also possibly stimulated a steadier multicrafting. The great increase in the frequency and proportion of pottery during the Late Horizon is evidence of a larger and more intensive occupation. Most of the Late Horizon sites are larger than 3,000 square meters, significantly larger than the Pre-Inca sites. For example, site $\mathrm{CH} 1$ has the largest number of structures, and occupies an area extending around 1.5 hectares (figure 6). Additionally, this mining camp is located at a strategic position in the entrance of Chinchilla ravine, at no more than 300 meters from both copper and iron oxide ore sources, and 
at only 3 kilometers from the Inca Road. Site $\mathrm{CH} 3$ is considerably denser in pottery than the others, which suggests that it was occupied either by more people, or during longer periods of time than the others.

Late Horizon mining camps were occupied more intensively and were interconnected by a network of informal trails bordering the mountains, thus facilitating the communication between mining groups. Despite these changes, these camps never changed their architectonic pattern of circular structures, and there is no evidence of Inca imposition of new buildings or public spaces here. From the radiocarbon dates obtained from $\mathrm{CH} 1$, it is visible that the occupation probably began sometime after the 1,000 AD, during the Late Intermediate Period (994 $\pm 39 \mathrm{BP}$ (AA104025), and $917 \pm 41 \mathrm{BP}$ (AA104026)). However, the bulk of the diagnostic ceramics date to the Late Period, and this is clearly the period of the most extensive and intensive occupation at the camp (536 \pm 33 BP (AA104028), and $431 \pm 36$ BP (AA104028)). Significantly, there is no material evidence of colonial occupation in the study area that could have altered the observed pattern of roadside mining-craft activities. Only at $\mathrm{CH} 1$, there is an area that had a short occupation in the mid- $20^{\text {th }}$ century for copper extraction, but it is separated and distinguishable from the prehispanic area.

To provide an additional quantitative assessment of the activity differences among sites for both periods, a Simpson's (1-L) diversity index was used to examine the degree of heterogeneity of the collection sample at confidence levels of $95 \%$ and $99 \%$. This analysis was based on proportions among sherds, lithics, copper ores, and red pigment fragments, using the sum of artifacts per collection unit at each site. In this analysis, values range from 0 (homogenous assemblage) to 1 (diverse assemblage). The more "specialized" a site in terms of assemblage, the lower the index. Figure 7 shows the average of all the individual site scores (including sites in Cachiyuyo de Llampos mountains, the Inca Road and artifact scatters in paths) per period, with a value for the Pre-Inca sites of 0.537 , and 0.463 for the Late Horizon sites. Hence, to a high degree of statistical significance, Pre Inca sites are less diverse than those of the Late Horizon. This finding indicates again that Pre-Inca Period sites tended to be more specialized in craft activities than the more "multicrafting" Late Horizon sites.

Overall, craft activities at the Cachiyuyo de Llampos sites during the Late Horizon were increased. There is continuity in the manufacture of lithic artifacts, turquoise, and malachite beads, the working of marine shell, and iron oxide red pigment grinding at the mining camps. This continuity provides further evidence that the miner-artisans did not dramatically change their mode of production during the Inca conquest. A partial explanation for multicrafting is related to the spatial proximity of the sources of copper ore and iron oxide. However, the decision to combine the production of multiple items may be more related to the "transferability" of some of the mining/crafting skills, as well as possibly reducing productive risks of uneven demand. Indirectly, the sociopolitical effects of the Inca conquest over the nearby Copiapó valley may have stimulated the consumption and demand of sumptuary goods by local mid-level elites allied to the empire, thus favoring the continuity of production of craft goods in the desert. Since multicrafting is a flexible strategy that can improve subsistence opportunities (Hirth 2009), it was likely used as a buffering strategy by the local miners, who expanded their production in order to benefit from the presence of the Inca Road.

Cachiyuyo de Llampos miners formed a mining community in the sense defined by Knapp (1998), representing the domestic space of diverse people working together during the time span determined by their common productive goal. These artisan-miners were independent producers organized in small household or corporate associations, sharing their physical space and raw resources. Mining was opportunistic, and followed a model of direct access to the resources (c.f. Pigott 1998), and there is also no evidence of elite control of production. Mining 
was done at the household level, where productivity was low and labor intensive; besides, in context of the marginal area where they lived, such mining activities provided comparatively better returns than agriculture (c.f. Shennan 1998, 1999). These camps do not show evidence of elite presence or social differentiation; artisan miners seem to have shared a similar social level with slight differences in the proportion of decorated pottery between household compounds. In brief, this suggests that the miners were an egalitarian association of household/corporate groups forming a community that share striking organizational similarities to ethnographic accounts of artisan mining. This is a marked contrast with the modes of corvée labor introduced by the Incas, from which there is no evidence here.

The evidence at the largest Late Horizon mining site $\mathrm{CH} 1$ suggests that the residents of specific groups of structures had spatial autonomy with multiple similar residential areas across the site (figure 6). The residents of each camp cooked their own food, without larger communal areas for that purpose. The decentralization of areas concerning food preparation/consumption and architecture compounds suggests the presence of a series of more or less distinct, independent residential units, such as household, or suprahousehold corporate groups, forming a mining community of $15-50$ people. Miners shared the ore veins and executed cooperative tasks related to the primary crushing and selection of the turquoise and malachite ores. Considering that there is only a single small source of water at the eastern part of Chinchilla ravine, some coordination between miner residents must have also been necessary to ensure a common access to the water well. The same is true for the provisioning of water to the travelers along the Inca Road who did not have other alternatives of water supply for dozens of kilometers around. This necessity may have helped to promote the exchange of crafts produced at the mining camps in Cachiyuyo de Llampos mountains.

With regards to the identity of the miners, their architecture, material culture, and craft production coincides with the local archaeological traditions from Copiapó Valley. During the Late Horizon, pottery styles show the involvement of local agents from Copiapó, and possibly other Diaguita commoners sharing similar spaces. Diaguita-Inca pottery styles became widely available in the region during Inca times, being used in similar contexts as local pottery in Copiapó Valley (Castillo 1998; Niemeyer 1986). Their presence is hence not ethnic-specific and reflect instead the presence of mid-level status items that were relatively easy to acquire in this new social context. 


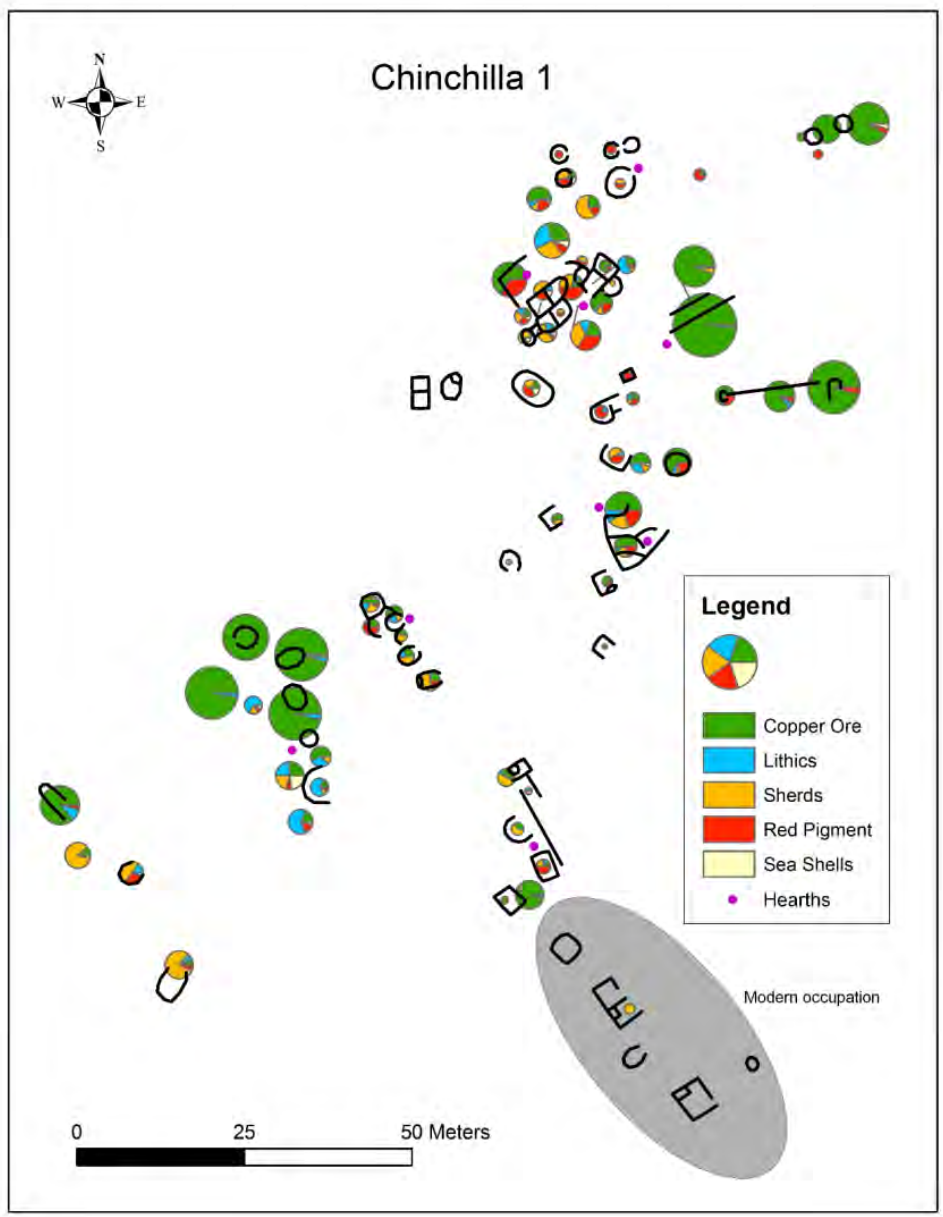

Figure 6. Map of artifact proportions and frequency at $\mathrm{CH} 1$ mining camp

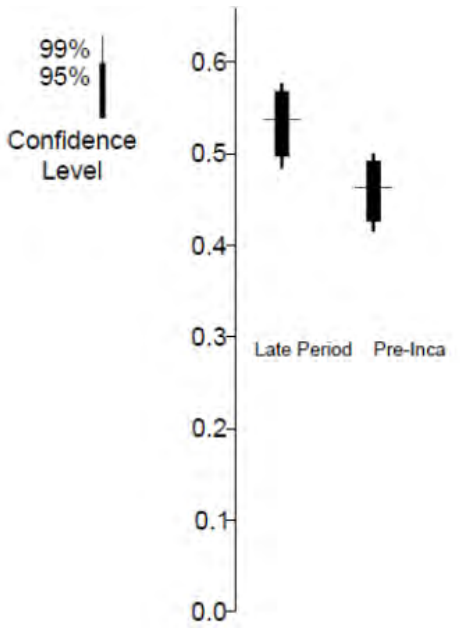

Figure 7. Bullet graphs showing Simpson's (1-L) diversity index for all Pre-Inca and Late Horizon sites 


\section{The Inca Road and circulating goods from the nearby mining-crafting activities}

In this section I will examine the archaeological evidence from the survey of the 12 kilometers of the nearby section of the Inca Road in front of Cachiyuyo de Llampos mountains. This will clarify the character the sites that are associated to it, and it will provide evidence for circulation of mining and craft products on the road. I present the following data to argue that the local miners moved their production to the Inca Road at non-Inca sites, suggesting that they exchange with travelers, and benefiting from its traffic and logistics capabilities. This constitutes an example of a "bottom-up" use of the Inca Road, an unintended effect from the point of view of Inca administrators.

The Inca Road in this area was placed over a rocky plain following a straight line in a north-eastsouthwest direction. It was built by cleaning the sandy surface from rocks that were left at the sides forming a shallow boundary (figure 8). In the 12 linear kilometers of the Inca road surveyed, 13 sites were identified (figure 5). They are mainly composed by one or two small circular/elliptical structures in immediate proximity to the road, without abundant presence of surface artifacts. These may have served as temporary shelters, and only few sites such as Exterior 9, QÑ5, QÑ8, and Tambo Medanoso seem to have supported larger numbers of people. If we consider that the infrastructure of the Inca road only served official purposes of travel and roadside sites are lodging posts to rest after daily journeys, it would be unlikely to find structures at distances that only average about 1 kilometer. Even the larger sites are too close to each other (4 km apart) to reflect a pattern where people used the road just to cross the desert, stopping the less possible to improve speed and efficiency of movement. In contrast, the actual site locations are more likely related to the presence of roadside activities, where some of the structures are reflecting connecting points to places outside the road.

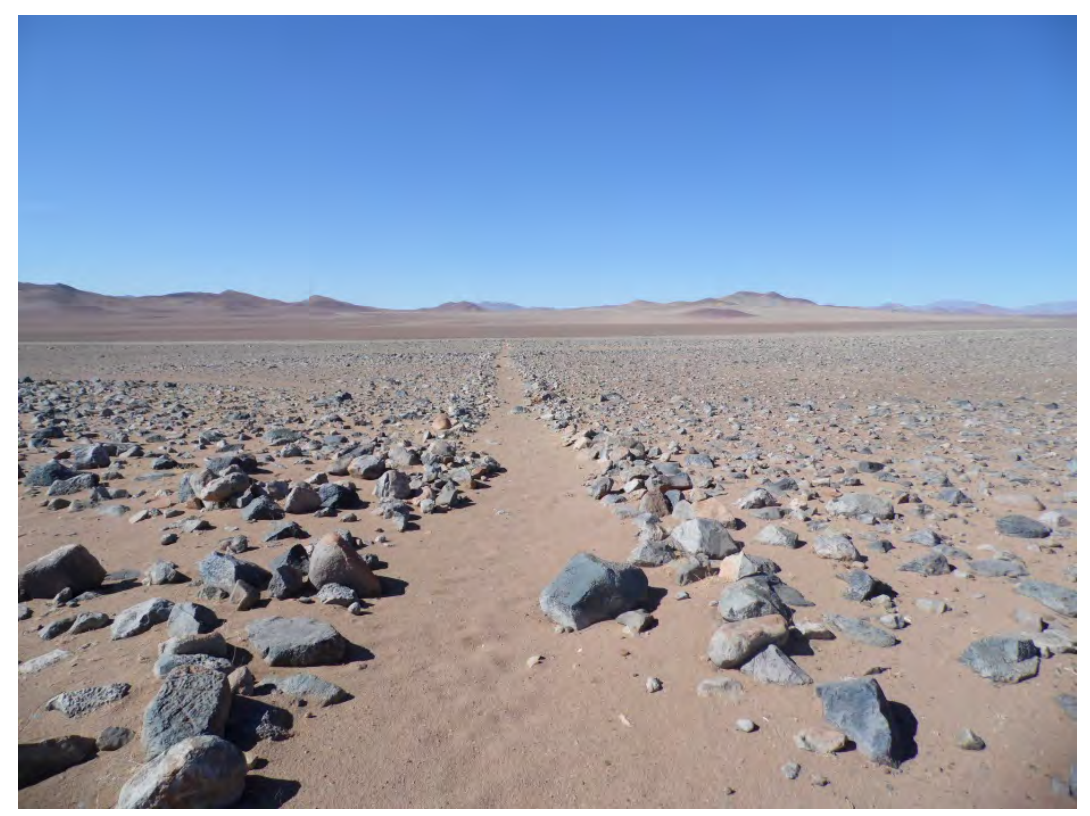

Figure 8. The Inca Road and the nearby Cachiyuyo de Llampos mountains

The intensity of traffic on the Inca Road was not homogeneous and there is a higher density of surface artifacts in the area located in front of Chinchilla ravine. Thus, sherd scatters of Inca and contemporary local styles are clustered in that area, because of its higher traffic frequency. In the survey area, the main cluster of surface pottery is located in between sites QÑ5 and QÑ 8 , 
which is the area in closest proximity to Cachiyuyo de Llampos mountains. Also, sites Exterior 9 and QÑ8 have clear signs of development of craft activities, such as copper ore processing for lapidary work, red pigment grinding, and manufacture of lithic artifacts. Their connection with the road suggests that they were important points where those products entered into the traffic either by the same artisan/miners producers, or through local middlemen.

\subsection{Tambo Medanoso as the official Inca outpost in the survey segment}

I have argued that in the survey area, local mining and craft activities developed independent of Inca control. Similarly, the lack of evidence for control of lapidary miners' economic activities suggests that Tambo Medanoso mainly served official activities as a lodging post in the desert on the route to Copiapó.

Tambo Medanoso is located at the southern end of the survey area and is the only site with a clear Inca architectural orthogonal pattern, as well as the largest internal spaces (figure 9). Sites such as the aforementioned QÑ5 and QÑ8, occupy a larger area than Tambo Medanoso because of the dispersion of their structures; however, they do not compare to the last one in the size of their residential spaces, nor have Inca orthogonal architecture. The structures of Tambo Medanoso consist of three main rectangular compounds with internal divisions and three small isolated semicircular structures in the southern end of the site. There is some evidence that the walls were double faced but they are mostly collapsed; they were constructed with nonmodified stones and the better preserved ones correspond to the internal divisions where the sand covers vertically over a meter of them. The southern compound is by far the largest, and contains in its northeast corner a large enclosed square space of 190 square meters that might correspond to a small public space or cancha surrounded by residential rooms. There is no evidence to interpret this space as a camelid corral, especially because of the lack of organic sediments from dung. Tambo Medanoso was built over an earlier occupation dating to the end of the Middle Period, as attested by two AMS radiocarbon dates $(1,229 \pm 41$ BP (AA104030), and 1,111 \pm 34 BP (AA104032)). The earliest date was obtained from an elliptical stone structure completely buried under the central compound of the tambo. The second early date comes from a circular structure located besides the orthogonal compounds of the tambo. Thus, it is clear that the Inca built this site over a previous but abandoned construction at the time the road was constructed. The dates for the Late Horizon indicate that the Tambo was occupied around the end of $14^{\text {th }}$ century and the beginning of $15^{\text {th }}$ century $(719 \pm 34$ BP (AA104031), and $559 \pm 41$ BP (AA104029)).

In terms of artifacts, Tambo Medanoso displays more prestige pottery than the mining camps but a very low presence of mining craft items. Tambo Medanoso has the higher proportion of decorated sherds of thin walls belonging to Inca local and Diaguita-Inca serving vessels, consisting in bowls, shallow plates, and aryballos. Thus, the evidence suggests that it did not have a special role in controlling or integrating with the activities of small-scale miners, who had their own posts built on the same Inca road. To expand on these differences, in the next section the assemblage of this site will be compared with the one from the mining camp $\mathrm{CH} 1$. 


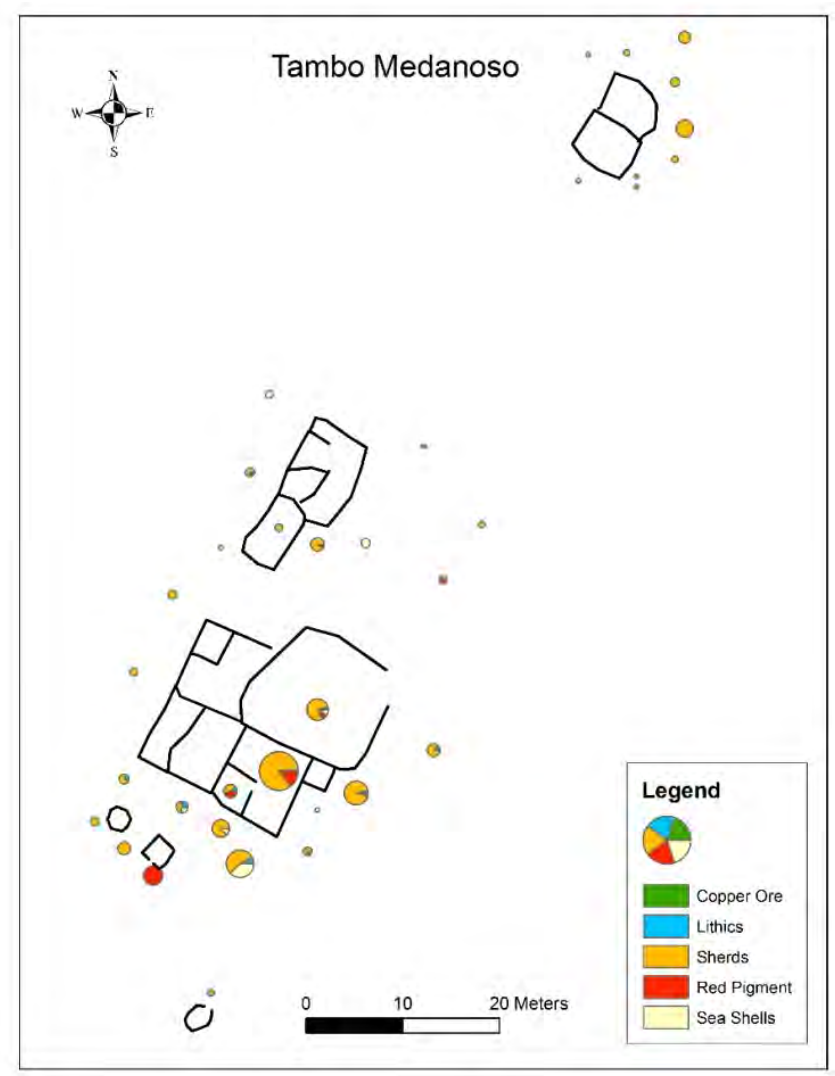

Figure 9. Map of artifact proportions and frequency at Tambo Medanoso

5.2 The worlds of the Inca state and local miners: a comparison between Tambo Medanoso and CH1 mining camp

Thus far, I have contended that the survey results show two "worlds": that of the Inca state, in the form of the road and the Tambo Medanoso, and that of local mining camps, including $\mathrm{CH} 1$. To highlight the differences between these two systems, this section will briefly compare excavated assemblages from Tambo and $\mathrm{CH} 1$ in terms of occupation, pottery preferences, activities, and food consumption.

In general, Tambo Medanoso exhibited lower artifact densities, both on the surface and in excavation, than $\mathrm{CH} 1$, indicating a low intensity occupation, and only a few residents on a more permanent basis. As shown to the left in figure 10, Tambo Medanoso and Chinchilla 1 represent opposite tendencies in terms of the proportion of decorated sherds, with a ratio of 3:1 for Tambo Medanoso versus $1: 3$ for $\mathrm{CH} 1$. This difference is highly significant under the Chi square test $\left(x^{2}=25.125, p<0.001\right)$. Inca local styles form a larger proportion of the Tambo Medanoso ceramic assemblage. This is not unexpected given the Tambo's official role along the Road. Yet, Inca local styles are a significant proportion of the assemblage at $\mathrm{CH} 1$ (and other mining camps) as well. 


\section{Pottery Decoration}

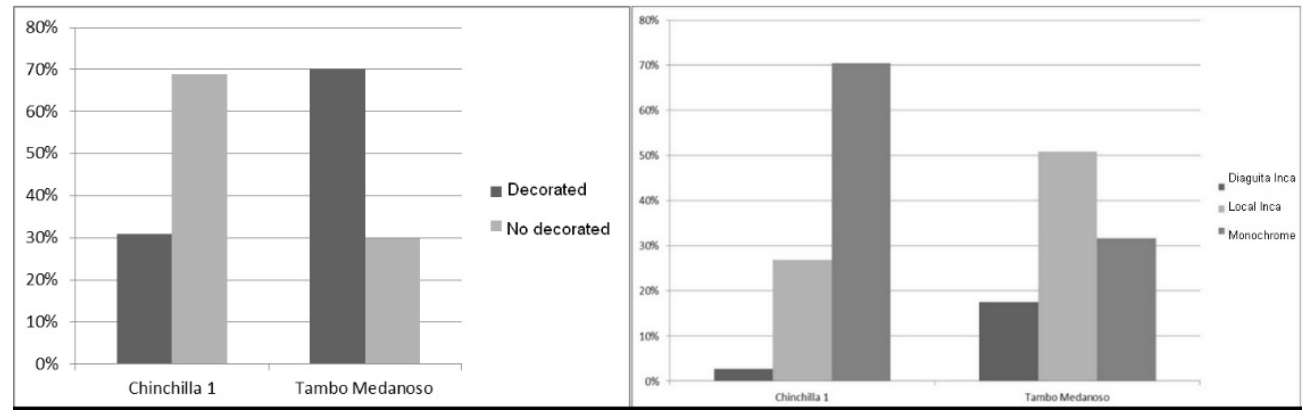

Figure 10. Presence of decoration, and styles in $\mathrm{CH} 1$ and Tambo Medanoso sherds

In comparison to $\mathrm{CH} 1$ miners, Tambo Medanoso residents: (1) used somewhat higher value pottery; (2) consumed more thin-walled, decorated, serving vessels (such as the Inca Local styles); and (3) used fewer large, thick-walled containers. The higher proportion of Monochrome sherds belonging to utilitarian cooking/container pots at $\mathrm{CH} 1$ is consistent with an intensive domestic occupation incorporating a full range of cooking, storage, and serving activities. At Tambo Medanoso, nearly all the pottery recovered in excavation came concentrated in the area immediate to the patio or cancha. These test pits were relatively contiguous in the southern compound at the site, and could represent an area of serving and consumption activities, separated from cooking and storage loci.

The diversity of raw materials of $\mathrm{CH} 1$ lithic artifacts suggests their residents were connected to a broader lithic exchange network than in Tambo Medanoso. Finished artifacts were found at $\mathrm{CH} 1$ but not at Tambo Medanoso. They consisted of five projectile points, including complete, broken, and unfinished ones, and two retouched artifacts that may have been used as knives or scrapers. No cores were found at either site, indicating the non-local nature of lithic source material, and that primary reduction largely did not take place at these sites. In terms of raw materials, basalt and silex dominated at both sites, but $\mathrm{CH} 1$ had a wider diversity of raw materials, including transparent quartz and obsidian obtained from the Andes mountains.

Both sites also differ in terms of their food consumption patterns, where the mining camps obtained most of their resources locally and each household had independent cooking-serving areas. No carbonized remains were recovered from Tambo Medanoso, while such were common in many test pits at $\mathrm{CH} 1$. This disparity may be related to the fewer hearths, overall, at Tambo Medanoso, suggestive of shorter occupations, or more consumption there of food that did not require cooking.

$\mathrm{CH} 1$ yielded chañar seeds (Greoffroeae decorticans), many of them charred. These fruits were likely transported dried from the Copiapó Valley, and were an important item of the miners' diet. Despite the great importance of maize and chicha to the Inca state, no maize remains were found neither at Tambo Medanoso nor $\mathrm{CH} 1$. In relation to animal remains, the identified taxa at each site reveals some significant differences. There is a much higher proportion at Tambo Medanoso of bony fish (Osteoichteyes), including the genre Genypterus sp.; one of the three species of the fish locally known as congrio (dorado, colorado y negro). Fish bones were a much lower proportion of the assemblage at $\mathrm{CH} 1$. In contrast, $\mathrm{CH} 1$ exhibits a higher proportion of rodents, including the family Chinchillidae (chinchillas and vizcachas), and the family Cricetidae which includes many small rodent species. If we group all the fish and rodent bones together, and compare their statistical significance per site using a Chi Square, the difference is highly significant with a $\mathrm{p}$ value $<0.001(\mathrm{x} 2=176.332$,). At both sites, bird bones (including 
Passeriformes) are a minor part of the assemblage (1\%), as is identified camelid bone $(2.08 \%$ in $\mathrm{CH} 1$ vs $1.85 \%$ in Tambo Medanoso). The broad Mamalia class includes a wide range of species (and non-diagnostic camelid), and represents $25 \%$ of the assemblage for $\mathrm{CH} 1$, and $35 \%$ for Tambo Medanoso.

In general, the evidence suggests that the residents of the mining camps had access to local resources obtained from hunting, in particular chinchillas, and brought wild fruits collected from far places such as Copiapó valley. In contrast, Tambo Medanoso shows a higher representation of fish, suggesting a connection with maritime resources, despite being located at about 100 kilometers from the coast.

\section{Discussion}

The Inca Road in this surveyed segment shows that the main traffic was not simply to and from Inca administrative sites. Instead, it shows a clear integration and intersection with the "off-road" traffic of people from and to the nearby local mining camps. The preexistent mining camps were relocated closer to the Inca Road, suggesting that the road had advantages for local populations, advantages that are not obviously related to an Inca co-option of the local economy. In order words, the road provided advantageous opportunities for the miners in terms of logistics and exchange. The Inca Road was to some extent appropriated to serve local and non-imperial economic purposes. This thus constitutes a unique "bottom-up" perspective of the Inca conquest beyond elite control. The evidence that better conditions for exchange was stimulated for miners consists of 1) presence on the Inca Road of mining-craft products similar to the ones produced in the nearby mining camps; 2) high density of structures with a local circular architectural pattern in between Inca tambos; 3) increasing in mining camp site area during the Late Horizon; 4) increasing in multicrafting; and 5) clustering of mining camps closer to the Inca Road in comparison to a previously dispersed pattern.

The comparison of the Tambo Medanoso with $\mathrm{CH} 1$ further illustrates the differences between the "world of the Road" and that of the mining communities. These differences underscore the extent to which these sites operated as part of different socioeconomic systems. Overall, $\mathrm{CH} 1$ exhibits a more intensive occupation. Multiple hearths at $\mathrm{CH} 1$ are consistent with the household socioeconomic organization at the site. In contrast, Tambo Medanoso exhibits centralized or communal food preparation and consumption areas. Although the sites share the same range of pottery styles, Tambo Medanoso displays higher proportions of decorated, thin-walled, and local Inca-style pottery, and lower proportions of large, thick-walled, plainware vessels. Although stone tool maintenance went on at each site, there was more tool making activity, with a wider range of non-local stone, at $\mathrm{CH} 1$. This stone, including obsidian, may not have travelled along the Road as part of Inca traffic. There are marked dietary differences between the sites, indicating that they did not share the same mechanism of resource acquisition. Fish consumption was more common at Tambo Medanoso, while wild rodents dominated the animal diet at $\mathrm{CH} 1$. Finally, the consumption of the local fruit chañar was limited to $\mathrm{CH} 1$. In sum, the Tambo Medanoso, and the Inca activities it represents, functioned independently of $\mathrm{CH} 1$ and the mining camps: two "systems" using the Road in different ways.

These changes in settlement pattern and production in the Cachiyuyo de Llampos mining system, I argue, demonstrate unexpected economic opportunities derived from the interconnection of isolated regions to broader social systems. On one hand, the Inca road brought new people and with them, more possibilities for roadside interaction and exchange. On the other, the road helped to improve the logistics of movement by providing staging and 
storage spaces, which in this case contributed to support more intensive mining activity. Considering that these miners were living in isolation and far from permanent settlements, it is unlikely that their production was intended for their own consumption. The Inca Road may have provided good opportunities for converting local generic commodities - such as beads and red pigment - into food and perhaps prestige goods - such as local styles of Inca pottery. It also further provided a predictable and probably safer place for practicing economic exchanges. In general, the mining camps injected a volume of new items into the Inca Road traffic; items that were not related to the political economy of the Inca Empire.

The only major Inca architectonical structure in the survey area, Tambo Medanoso, did not have an important logistic role for storage of mining products or food items. Resources for miners may therefore have been autonomously provided, and supply and exchange probably occurred at the non-Inca structures along the road. The main purpose of the tambo does not seem to have gone far beyond the support of official travelers. However, the circular structures on the road served as dwellings and crafting places. These were evidently crucial for the local economic involvement of miners and artisans with the Inca road network and its global connections. This is an important contrast to other examples of state-centralized modes of Inca mining/metallurgic work in the Andes, which describe a large concentration of food serving areas, public spaces, and formal Inca architecture (c.f. Berthelot 1986; Cantarutti 2013; Cruz and Vacher 2008; D'Altroy and Earle 1985; Earle 1994; Lechtman 2007; Salazar 2008; Salazar et al. 2010; Salazar et al. 2013; Van Buren and Presta 2010; Williams 2000). The Incas did not integrate these miners within the political economy of the empire, possibly because of their isolation, low productivity, lack of hierarchical organization, and the likelihood that their products were irrelevant to state wealth. Most of the Inca economic activities in the region were carried out in Copiapó valley in relation to the metallurgical facility of Viña del Cerro and other administrative centers such as La Puerta and Iglesia Colorada, which may have been in charge of production and distribution of prestige items for the imperial political economy. The production of beads followed an independent pattern of sumptuary goods destined for the local populations of the valley, either commoners or intermediate elites.

\section{Conclusion}

Building on various complementary studies, such as comparative investigation of ancient Roman provincial roads (Foubert and Breeze 2014; Hitchner 2012; Speidel 1987; Talbert 2012; Wiseman 1970; Witcher 1998), the spread of modern transportation nets (Fogel 1962; Harvey and Knox 2015), and modern llama caravan activities in the Andes (Nielsen 2000, 2001, 2009, 2013), we can now begin to interrogate the Inca Road differently. These studies reveal the potential local economic impacts of roads, highlighting that traffic on roads creates increased opportunities for social relations, exchange, and in lowering transport costs directly or through middlemen, the road itself becomes a "growth factor" stimulating locally productive activities. Far from being closed systems, ancient roads have the potential to function as loci for roadside marketing and bartering, down-the-line local exchange, and as places of accumulation and distribution. In describing the modern day activities of llama caravans along well-established routes, Nielsen (2000:438-439) notes the importance of "secondary exchange" and "daily swapping" during the journey, with caravaneers taking advantage of local trade opportunities along the route, either in nearby villages or when local people come to the route to barter for goods. Intriguingly, Murra (1980) may have been the first to suggest the possible connection between the Inca Road and "barter" activity. While observing that "Garcilaso's notion that there was little traffic on the road beyond the official business is a widespread one," Murra (1980:147) cites (but does not present) "ample" evidence for commoner traveling folk (including merchant 
types) who "paid" tolls at bridges and for lodging at tambos. Roads provide a different kind of interaction than forts or administrative centers, due to their inter-nodal characteristic, which allows more room for interstitial activities that cannot or were not in the interest of being totally controlled by the top authorities.

Cachiyuyo de Llampos mining system is an example of craft specialization that started long before the arrival of the Inca state, where full time miners and artisans labored in the desert leaving aside production for subsistence in agricultural areas. The incidental placement of the Inca Road nearby the mining camps, provided a supply line to isolated sites, and this article has presented data to argue that the increase in local traffic stimulated the exchange of mining craft products. There is no evidence that local residents were economically coerced by the Incas; their production followed a previous decentralized pattern, thus coexisting with centralized forms of Inca mining visible elsewhere in the Atacama desert and the central Andes. These local miners developed their activities parallel to the Inca imperial economy, and likely took advantage of a possibly higher demand of sumptuary products related to the emergence of new local elites involved in the Inca administration. Crafting in the desert may have become attractive for the manufacture of products of high value for exchange, because of the distance and labor invested in their production (Dillian and White 2010). Beads and pigments were not cheap to be produced, and they should have been valuable enough to justify their consistent exploitation over at least two millennia. However, the political and social changes derived from the Inca political conquest may have also increased the local demand of sumptuary goods in Copiapó valley, thus fostering mining specializations in the desert.

This paper has thus provided an example to question assumptions that Andean household units were economically passive. Instead, their roadside bartering activities constitute evidence that they did not just increase their production in function of top-down demands, but that they also found independent economic opportunities as a "grass roots" response to imperial conquest. Local interaction with overarching polities can only be visible through new research questions focused on the local perception and action over imperial infrastructure. The "infrastructural power" of the state (Mann $(1984,2008)$, of which the Inca Road is a clear example, probably could not escape being contested and partially overtaken by provincial groups due to the logistical constraints that the empire faced in its expansion. This possibility could be extended to other kinds of official infrastructure in ancient empires when interacting with local social groups and negotiating with their particular agendas.

To conclude, the "imperial landscape" created by the Qhapaq Ñan (c.f. Julien 2012) was more permeable than what the Incas expected, despite the physical or ideological coercion they may have tried to enforce. And this is more than plausible at thousands of kilometers from Cuzco, where the control of the empire relied heavily on local alliances, and the possibilities for surveillance were clearly limited.

\section{Acknowledgements}

I acknowledge and am grateful for the generous funding provided by the following organizations: Wenner-Gren Foundation for fieldwork research (grant 8704), National Science Foundation for lab analysis (grant 1359661), and Fulbright and The Heinz Endowments for tuition and dissertation writing respectively. Their funding made this dissertation research possible. I would also like to acknowledge the support of my advisor Marc Bermann, and my dissertation 
committee for their support in the execution of this work. Many colleagues and peers in Pittsburgh and Chile contributed to this endeavor through lively discussions, or assistance with excavations and analyses. The thoughtful comments of anonymous reviewers of previous drafts helped to strengthen my discussions and arguments. To all of them I am sincerely thankful.

\section{References}

Adán, L., 1999. Aquellos Antiguos Edificios. Acercamiento arqueológico a la arquitectura prehispánica tardía de Caspana. Estudios Atacameños 18, 13-33.

Amin, A., 2014. Lively Infrastructure. Theory, Culture \& Society 31(7/8), 137-161.

Ampuero, G. 1978. Cultura Diaguita. Ministerio de Educación, Departamento de Extensión Cultural, Santiago.

Astuhuamán, C., 2004. Pariacaca: Un oráculo imperial Andino. Ensayos en Ciencias Sociales 1(2), 15-54.

Banerjee, A., Duflo, E., Qian, N., 2012. On the road: access to transportation infrastructure and economic growth in China. MIT Working Papers 12. MIT, Department of Economics, Cambridge, pp.1-50.

Berenguer, J., 2007. El camino Inka del Alto Loa y la creación del espacio provincial en Atacama. In: Nielsen, A., Rivolta, C., Seldes, V., Vázquez, M., Mercolli, P., (Eds), Producción y circulación prehispánicas de bienes en el sur andino. Editorial Brujas, Córdoba, pp.413-443.

Berenguer, J. 2009. Chile bajo el imperio de los Inkas. Museo Chileno de Arte Precolombino, Santiago.

Berenguer, J., 2004. Caravanas, interacción y cambio en el desierto de Atacama. Editorial Sirawi, Santiago.

Berenguer, J., Cáceres, I. 2008. Los Inkas en el altiplano sur de Tarapacá: El Tojo revisitado. Chungará 40(2), 121-143.

Berenguer, J., Cáceres, I., Sanhueza, C., Hernández, P., 2005. El Qhapaqñan en el Alto Loa, norte de Chile: un estudio micro y macromorfológico. Estudios Atacameños 29, 7-39.

Berthelot, J., 1986. The extraction of precious metals at the time of the Inka. In: Murra, J., Wachtel, N., Revel, J., (Eds.), Anthropological history of Andean polities. Cambridge University Press, Cambridge, pp. 69-88.

Bibar, G. 1966. Crónica y relación copiosa y verdadera de los reinos de Chile. Fondo Histórico y Bibliográfico José Toribio Medina. Instituto Geográfico Militar, Santiago.

Bryceson, D., Bradbury, A., Bradbury, T., 2008. Roads to poverty reduction? Exploring rural roads impact on mobility in Africa and Asia. Development policy review 26(4), 459-482.

Canning, D., Fay. M., 1993. The effects of transportation networks on economic growth. Discussion papers series, Department of Economics. Columbia University, New York, pp.1-47. 
Cantarutti, G., 2013. Mining under Inca rule in north-central Chile: the Los Infieles mining complex. In: Tripcevich, N., Vaughn, K., (Eds.), Mining and quarrying in the ancient Andes. Springer, New York, Heidelberg, Dordrecht, London, pp.185-212.

Castillo, G., 1998. Los períodos intermedio tardío y tardío: desde la cultura Copiapó al dominio Inca. In: Niemeyer, H., Cervellino, M., Castillo, G. (Eds.), Culturas Prehistóricas de Copiapó. Museo Regional de Atacama, Copiapó, pp.163-282.

Castro, V., Varela, V., Aldunate, C., Varela, E., 2004. Principios orientadores y metodología para el estudio del Qhapaqñan en Atacama: desde el portezuelo del Inka hasta Río Grande. Chungara 36, 463-481.

Clark, J., Blake, M., 1994. The power of prestige: competitive generosity and the emergence of rank societies in lowland Mesoamerica. In: Brumfiel, E., Fox, J. (Eds.), Factional competition and political development in the new world. Cambridge University Press, Cambridge, pp.17-30.

Chu, J., 2014. When infrastructures attack: The workings of disrepair in China. American Ethnologist 41(2), 351-367.

Cornejo, L. 1999. Los incas y la construcción del espacio en Turi. Estudios Atacameños 18, 165-176.

Cornejo, L. 2001. Los Inka y sus aliados Diaguita en el extremo austral del Tawantinsuyu. In: Tras la huella del Inka en Chile. Museo Chileno de Arte Precolombino, Santiago, pp. 74-89.

Cornely, F. 1956. Cultura Diaguita Chilena: y Cultura de El Molle. Editorial del Pacífico, Santiago.

Cruz, P., Vacher, J., (Eds.), 2008. Metalurgia en los Andes del sur desde la época prehispánica hasta el siglo XVII. Instituto Francés de Estudios Andinos, Sucre.

D'Altroy, T., 1992. Provincial power in the Inka empire. Smithsonian Institution Press, Washington D.C.

D'Altroy, T., 2002a. From autonomous to imperial rule. In: D'Altroy, T., Hastorf C., (Eds.), Empire and Domestic Economy. Kluwer Academic/Plenum Publishers, New York, pp. 325-339.

D'Altroy, T., 2002b. The Incas. Blackwell Publishing, Malden.

D’Altroy, T., 2015. The Incas (Second edition). Blackwell Publishing, Malden.

D'Altroy, T., Earle, T., 1985. Staple finance, wealth finance, and storage in the Inka political economy. Current Anthropology 26 (2), 187-206.

De Ayala, G. P. 1980. Nueva Coronica y buen Gobierno. Biblioteca Ayacucho, Caracas.

De la Vega, G. 1991. Comentarios Reales de los Incas. Biblioteca Ayacucho, Caracas.

De Murúa, M. 2001. Historia General del Perú. Crónicas de América. Dastin, Madrid.

Dillian, C., White, C., 2010. Introduction: perspectives on trade and exchange. In: Dillian, C., White, C (Eds.), Trade and exchange archaeological studies from history and prehistory. Springer, New York, Dordrecht, Heidelberg, London, pp. 3-15.

Douglass, J., 2002. Hinterland households: rural agrarian household diversity in northwest Honduras. University Press of Colorado, Boulder. 
Earle, T., 1994. Wealth finance in the Inka empire: evidence from the Calchaquí valley, Argentina. American Antiquity 59(3), 443-460.

Earle. T., 2002. Exchange and social stratification in the Andes: the Xauxa case. In: T. D'Altroy and C. Hastorf (Eds.), Empire and Domestic Economy. Kluwer Academic/Plenum Publishers, New York, pp. 297-314.

Earle, T., 2009. Routes through the landscape: a comparative approach. In Landscapes of movement trails, paths, and roads in anthropological perspective. James Snead, Clark Erickson, Andrew Darling, eds. Pp.253-269. Philadelphia: University of Pennsylvania Museum of Archaeology and Anthropology.

Earle, T., Smith, M., 2012. Households, economies, and power in the Aztec and Inka imperial provinces. In: Smith, M., (Ed.), The comparative archaeology of complex societies. Cambridge University Press, New York, pp. 238-284.

Falconer, S., 1995. Rural responses to early urbanism: Bronze Age household and village economy at Tell el-Hayyat, Jordan. Journal of Field Archaeology 22(4), 399-419.

Feinman, G., Nicholas, L., 2004. Unraveling the prehispanic highland Mesoamerican economy. Production, exchange, and consumption in the classic period valley of Oaxaca. In: Feinman, G., Nicholas, L., (Eds.), Archaeological perspectives on political economies. University of Utah Press, Salt Lake City, pp.167-188.

Feinman, G., Blanton, R., Kowalewski, S., 1984. Market system development in the prehispanic valley of Oaxaca, Mexico. In: Kenneth $\mathrm{H}_{\text {., }}(\mathrm{Ed}$.), Trade and exchange in early Mesoamerica. University of New Mexico Press, Albuquerque, pp.157-178.

Fernández de Oviedo, G. 1855. Historia general y natural de las Indias, Islas y Tierra-Firme del Mar Oceano. Volume IV, third part. Imprenta de la Real Academia de la Historia, Madrid.

Fogel, R., 1962. A quantitative approach to the study of railroads in American economic growth: a report of some preliminary findings. Journal of Economic History 22 (2), 163-197.

Foubert, L., Breeze, D., 2014. Mobility in the Roman empire. In: Leary, J., (Ed.), Past mobilities: archaeological approaches to movement and mobility. Ashgate Publishing Ltd., Farnham, pp.175-186.

Gallardo, F., 2013. Sobre el comercio y mercado tradicional entre los Lupaca del siglo XVI: un enfoque económico sustantivo. Chungara 45 (4), 599-612.

Gonlin, N., 2012. Production and consumption in the countryside: a case of study from the late classic Maya rural commoner households at Copán, Honduras. In: Douglass, J., Gonlin, N., (Eds.), Ancient households of the Americas: conceptualizing what households do. University Press of Colorado, Boulder, pp.79-116.

González, P. 2000. Patrones decorativos de las culturas agroalfareras de la Provincia del Choapa y su relación con los desarrollos culturales de las áreas aledañas (Norte Chico y Zona Central). In: Actas del XIV Congreso Nacional de Arqueología Chilena, Sociedad Chilena de arqueología, Arica, pp. 191-221.

González, C., Westfall, C., 2010. Qhapaq Ñan, arquitectura, vernácula y del Inka en El Salvador, región de Atacama. Reconocimientos iniciales. In: Actas del XVII Congreso Nacional de Arqueología Chilena. Sociedad Chilena de arqueología, Valparaíso, pp. 887-897. 
Harvey P., Knox, H., 2015. Roads: an anthropology of infrastructure and expertise. Cornell University Press, Ithaca and London.

Hassig, R., 1991. Roads, routes, and ties that bind. In: Trombold, C. (Ed.), Ancient road networks and settlement hierarchies in the new world. Cambridge University Press, Cambridge, pp.17-27.

Hendon, J., 1996. Archaeological approaches to the organization of domestic labor: household practice and domestic relations. Annual review of anthropology 25, 45-61.

Herbert, E., 1998. Mining as microcosm in precolonial sub-Saharan Africa. An overview. In: Herbert, E., Knapp, B., Pigott, V., (Eds.). Social approaches to an industrial past: the archaeology and anthropology of mining. Routledge, London, pp.138-154.

Hirth, K., 1998. The distributional approach: a new way to identify marketplace exchange in the archaeological record. Current Anthropology 39, 451-467.

Hirth, K., 2009. Craft production, household diversification, and domestic economy in prehispanic Mesoamerica. Archaeological papers of the American anthropological association $19,13-32$.

Hirth, K., 2010. Finding the mark in the marketplace: the organization, development, and archaeological identification of market systems. In: Garraty, C., Stark, B., (Eds.). Archaeological approaches to market exchange in ancient societies. University Press of Colorado, Boulder, pp.227-247.

Hitchner, B., 2012. Roads, integration, connectivity, and economic performance in the Roman empire. In: Alcock, S., Bodel, J., Talbert, R., (Eds.), Highways, byways, and road systems in the pre-modern world. Wiley \& Sons, Inc., Malden, pp.222-234.

Hyslop, J., 1984. The Inka road system. Institute of Andean Research, New York.

Hyslop, J., 1990. Inka Settlement Planning. University of Texas Press, Austin.

INC. 2005-2009. Proyecto Qhapaq Ñan: informe de campaña. Volumes 1-8. Instituto Nacional de Cultura (INC), Lima.

Iribarren, J., 1972. Una Mina de Explotación Incaica en El Salvador Provincia de Atacama. In: Actas del VI congreso nacional de arqueología Chilena. Sociedad Chilena de arqueología, Santiago, 267-283.

Iribarren, J., Bergholz, H., 1972. El camino del Inca en un sector del norte chico. In: Actas del VI congreso nacional de arqueología Chilena. Sociedad Chilena de arqueología, Santiago, pp.229266.

Jenkins, D., 2001. A network analysis of Inka roads, administrative centers, and storage facilities. Ethnohistory 48 (4), 655-687.

Julien, C., 2012. The Chincaysusyu road and the definition of an Inca imperial landscape. In: Alcock, S., Bodel, J., Talbert, R., (Eds.), Highways, byways, and road systems in the premodern world. Wiley \& Sons, Inc., Malden, pp.147-167.

Julien, C., 2004. Hatunqolla, una perspectiva sobre el imperio Incaico desde la región del lago Titicaca. CIMA editores, La Paz. 
Knapp, B., 1998. Social approaches to the archaeology and anthropology of mining. In: Herbert, E., Knapp, B., Pigott, V., (Eds.). Social approaches to an industrial past: the archaeology and anthropology of mining. Routledge, London, pp.1-23.

Kreutzmann, H., 1991. The Karakoram highway: the impact of road construction on mountain societies. Modern Asian studies 25(4), 711-736.

Larkin, B., 2013. The politics and poetics of infrastructure. Annual Review of Anthropology 42, 327-43.

Letchman, H., 2007. The Inka, and Andean metallurgical tradition. In: Burger, R., Morris, C., Matos, R., (Eds.), Variations in the expression of Inka power. Dumbarton Oaks research library and collection, Washington DC., pp.313-356.

Letchman, H., MacFarlane, A., 2006. Bronce y redes de intercambio Andino durante el horizonte medio: Tiwanaku y San Pedro de Atacama. In: Lechtman, H., (Ed.), Esferas de interacción prehistóricas y fronteras nacionales modernas: los Andes sur centrales. Instituto de Estudios Peruanos de Lima-Institute of Andean Research, Lima, pp.503-539.

Lynch, T., 1993. The identification of Inca posts and roads from Catarpe to río Frío, Chile. In: Malpass, M., (Ed.), Provincial Inca, archaeological and ethnohistorical assessment of the impact of the Inca state. University of lowa Press, lowa City, pp.117-142.

Lynch, T., 1995-6. Inka roads in the Atacama: effects of the later use by mounted travelers. Diálogo Andino 14-15, 187-203.

Lynch, T., Núñez, L., 1994. Nuevas evidencias Inkas entre Kollahuasi y río Frío (I y II regiones de Chile). Estudios Atacameños 11, 145-165.

Marcus, J., 2006. Identifying elites and their strategies. In: Elston, C., Covey, A., (Eds.), Intermediate elites in pre-columbian states and empires. The University of Arizona Press, Tucson, pp.212-246.

Mann, M., 1984. The autonomous power of the state: its origins, mechanisms and results. Archives Europeennes de sociologie 25, 185-213.

Mann, M., (2008). Infrastructural power revisited. Studies in Comparative International Development (SCID), 43(3), 355-365.

Maksaev, V., Townley, B., Palacios, C., Camus, F., 2007. Metallic ore deposits. In: Moreno, T., Gibbons, W., (Eds.), The geology of Chile. Geological Society Publishing House, London, pp.179-199.

Martin, A., 2010. The Domestic Economy and its Implications for Social Complexity: Spondylus Craft Production in Coastal Ecuador. Research in Economic Anthropology 30, 111-155.

Mayer, E., 2013. In the realm of the Incas. In: Hirth, K., Pillsbury, J., (Eds.), Merchants, markets, and exchange in the pre-columbian world. Dumbarton Oaks Research Library and Collection, Washington D.C., pp.309-318.

Mills, B., 2007. Multicrafting, identity, and migration in the American southwest. In: Shimada, I. (Ed.), Craft production in complex societies, multicraft and producer perspectives. The University of Utah Press, Salt Lake City, pp.25-43.

Murra, J., 1980. The Economic Organization of the Inka State. Research in economic anthropology, supplement 1. JAI Press, Greenwich. 
Murra, J., 1995. Did tribute and markets prevail in the Andes before the European invasion?. In: Larson, B., Harris, O., (Eds.), Ethnicity, markets, and migration in the Andes: at the crossroads of history. Duke University, Durham, pp.57-72.

Netting, R., 1993. Smallholders, householders: farm families and the ecology of intense, sustainable agriculture. Stanford University Press, Stanford.

Nielsen, A., 2013. Circulating objects and the constitution of south Andean society. In: Hirth, K., Pillsbury, J., (Eds.), Merchants, markets, and exchange in the pre-columbian world. Dumbarton Oaks Research Library and Collection, Washington D.C., pp.389-418.

Nielsen, A., 2009. Pastoralism and the non-pastoral world in the late pre-columbian history of the southern Andes (1000-1535). Nomadic Peoples 13(2), 17-35.

Nielsen, A., 2001. Ethnoarchaeological perspectives on caravan trade in the south-central Andes. In: Kuznar, L. (Ed.), Ethnoarchaeology of Andean South America contributions to archaeological method and theory. International Monographs in Prehistory, Ethnoarchaeological series 4, Ann Arbor, pp.163-201.

Nielsen, A., 2000. Andean caravans: an ethnoarchaeology. Phd Dissertation in Anthropology. University of Arizona, Tucson.

Niemeyer, H., Cervellino, M., Castillo, G. 1993. Estrategia del dominio Inca en el valle de Copiapó. Boletín del Museo Regional de La Araucania, 333-371.

Niemeyer, H., 1986. La ocupación incaica en la cuenca alta del rio Copiapó. Revista Comechingonia, Special Issue, El imperio Inka, actualización y perspectivas por registros arqueológicos y etnohistóricos, 165-294.

Niemeyer, H., Rivera, M., 1983. El Camino del Inca en el Despoblado de Atacama. Boletín de Prehistoria de Chile 9, 91-193.

Nylan, Michael. 2012. The power of highway networks during China's classical era (323 BCE316 CE): regulations, metaphors, rituals, and deities. In: Alcock, S., Bodel, J., Talbert, R., (Eds.), Highways, byways, and road systems in the pre-modern world. Wiley \& Sons, Inc., Malden, pp.33-65.

OECD. 2002. Impact of Transport Infrastructure Investment on Regional Development. OECD Publishing, Paris.

Pigott, V., 1998. Prehistoric copper mining in the context of emerging community craft specialization in northeast Thailand. In: Herbert, E., Knapp, B., Pigott, V., (Eds.). Social approaches to an industrial past: the archaeology and anthropology of mining. Routledge, London, pp.205-225.

Raffino, R., 1982. Los Inkas del Kollasuyu. Ramos americana, La Plata.

Rostworowski, M., 1989. Costa Peruana prehispánica. Instituto de estudios Peruanos, Lima.

Salazar, D., 2008. La producción minera en San José del Abra durante el período tardío Atacameño. Estudios Atacameños 36, 46-72.

Salazar, D., Borie, C., Oñate, C., 2013. Mining, commensal politics, and ritual under Inca rule in Atacama, northern Chile. In: Tripcevich, N., Vaughn, K., (Eds.), Mining and quarrying in the ancient Andes. Springer, New York, Heidelberg, Dordrecht, London, pp.253-274. 
Salazar, D., Salinas, H., McRostie, V., Labarca, R., Vega, G., 2010. Cerro Turquesa: diez siglos de producción minera en el extremo norte de Chile. In: Actas del XVII congreso nacional de arqueología Chilena. Sociedad Chilena de arqueología, Valparaíso, pp.1085-1097.

Salomon, F., 1986. Vertical politics on the Inka frontier. In: Murra, J., Wachtel, N., Revel, J., (Eds.), Anthropological history of Andean polities. Cambridge University Press, Cambridge, pp.89-117.

Segerstrom, K., 1960. Cuadrángulo Llampos, provincia de Atacama. Instituto de Investigaciones Geológicas de Chile, Santiago.

Shennan, S., 1998. Producing copper in the eastern Alps during the second millennium BC. In: Herbert, E., Knapp, B., Pigott, V., (Eds.). Social approaches to an industrial past: the archaeology and anthropology of mining. Routledge, London, pp.191-204.

Shennan, S., 1999. Cost, benefit and value in the organization of early European copper production. Antiquity 73, 352-363.

Shimada, I., 2007. Introduction. In: Shimada, I. (Ed.), Craft production in complex societies, multicraft and producer perspectives. The University of Utah Press, Salt Lake City, pp.1-21.

Smith, M., Heath-Smith, C., 1994. Rural economy in late postclassic Morelos: An archaeological study. In: Hodge, M., Smith, M., (Eds.), Economies and polities in the Aztec realm. Institute for Mesoamerican Studies, Albany, pp.349-376.

Smith, M., Wharton, J., Olson, J., 2003. Aztec feasts, rituals, and markets: political uses of ceramic vessels in a commercial economy. In: Bray, T. (Ed.), The archaeology and politics of food and feasting in early states and empires. Kluwer Academic/Plenum Press, New York, pp.235-270.

Snead, J., 2012. Obliterated itineraries: Pueblo trails, Chaco roads, and archaeological knowledge. In: Alcock, S., Bodel, J., Talbert, R., (Eds.), Highways, byways, and road systems in the pre-modern world. Wiley \& Sons, Inc., Malden, pp.106-127.

Speidel, M., 1987. The Roman road to Dumata (Jawf in Saudi Arabia) and the frontier strategy of praetensione colligare. Historia: zeitschrift für alte geschichte 36(2), 213-221.

Stanish, C., 2010. Labor taxes, market systems, and urbanization in the prehispanic Andes: A comparative perspective. In: Garraty, C., Stark, B. (Eds.), Archaeological approaches to market exchange in ancient societies. University Press of Colorado, Boulder, pp.185-205.

Stanish, C., Coben, L., 2013. Barter markets in pre-hispanic Andes. In: Hirth, K., Pillsbury, J., (Eds.), Merchants, markets, and exchange in the pre-columbian world. Dumbarton Oaks Research Library and Collection, Washington D.C., pp.419-434.

Stark, B., Garraty, C., 2010. Detecting marketplace exchange in archaeology: a methodological review. In: Garraty, C., Stark, B. (Eds.), Archaeological approaches to market exchange in ancient societies. University Press of Colorado, Boulder, pp.33-58.

Stehberg, R., 1995. Instalaciones incaicas en el norte y centro semiárido de Chile. Centro de Investigaciones Diego Barros Arana, DIBAM, Santiago.

Talbert, R., 2012. Roads not featured: a Roman failure to communicate? In: Alcock, S., Bodel, J., Talbert, R., (Eds.), Highways, byways, and road systems in the pre-modern world. Wiley \& Sons, Inc., Malden, pp.235-254. 
Topping, P., Lynott, M., 2005. Miners and mines. In: Topping, P., Lynott, M. (Ed.s), The cultural landscape of prehistoric mines. Oxbow Books, Oxford, pp.181-191.

Uribe, M. 2000. La arqueología del Inka en Chile. Revista Chilena de Antropología 15, 63-97.

Uribe, M., Urbina, S. 2009. Cerámica y Arquitectura Pública en el Camino del Inka del Desierto de Atacama (Río Loa, Norte Grande de Chile). Revista de Antropología N²0, 227-260.

Uribe, M., Adán, A. 2004. Acerca del dominio Inka, sin miedo, sin vergüenza. Chungará 36, 467-480.

Van Buren, M., Presta, A., 2010. The organization of Inka silver production in Porco, Bolivia. In: Malpass, M., Alconini, S., (Eds.), Distant provinces in the Inka empire. University of lowa Press, lowa City, pp.173-192.

Vaporis, C., 2012. Linking the realm: the Gokaidô highway network in early modern Japan (1603-1868). In: Alcock, S., Bodel, J., Talbert, R., (Eds.), Highways, byways, and road systems in the pre-modern world. Wiley \& Sons, Inc., Malden, pp.90-105.

Vitry, C., 2007. Caminos rituales y montañas sagradas. Estudio de la vialidad inka en adoratorios de altura del norte Argentino. Boletín del museo chileno de arte precolombino 12(2), 69-84.

Vitry, C., 2000. Aportes para el estudio de caminos incaicos. Tramo Morohuasi-Incahuasi, Salta, Argentina. Universidad Nacional de Salta, Salta.

Westfall, C., Gonzalez, C., 2010. Mina Las Turquesas: Un asentamiento minero lapidario preincaico en el extremo meridional circumpuneño, región de Atacama, Chile. In: Actas del XVII congreso nacional de arqueología Chilena. Sociedad Chilena de Arqueología, Valdivia, pp.1073-1083.

Wilk, R., 1989. Decision making and resource flows within the household: beyond the black box. In: Wilk, R. (Ed.), The Household Economy. Westview, Boulder, pp.23-52.

Williams, V., 2000. El Imperio Inka en la Provincia de Catamarca. Intersecciones en Antropología 1, 55-79.

Wiseman, T., 1970. Republican Road-Building. Papers of the British School at Rome 38, 122152.

Witcher, R., 1998. Roman Roads: Phenomenological Perspectives on Roads in the Landscape. In: TRAC 97: Proceedings of the seventh annual theoretical Roman archaeology conference. University of Nottingham, Oxford, pp.60-70.

Zori, C., Urbina, S. 2014. Architecture and empire at late prehispanic Tarapacá Viejo, northern Chile. Chungara 46 (2), 211-232.

Zori, C., Tropper, P. 2013. Silver lining: evidence for Inka silver refining in northern Chile. Journal of Archaeological Science 40(8), 3282-3292.

Zori, C., Tropper, P., Scott, D. 2013. Copper production in late prehispanic northern Chile. Journal of Archaeological Science 40(2), 1165-1175.

Zori, C., Tropper, P. 2010. Late pre-Hispanic and early Colonial silver production in the Quebrada de Tarapacá, Northern Chile. Boletín del Museo Chileno de Arte Precolombino 15(2), 65-87. 


\section{Graphical Abstract}
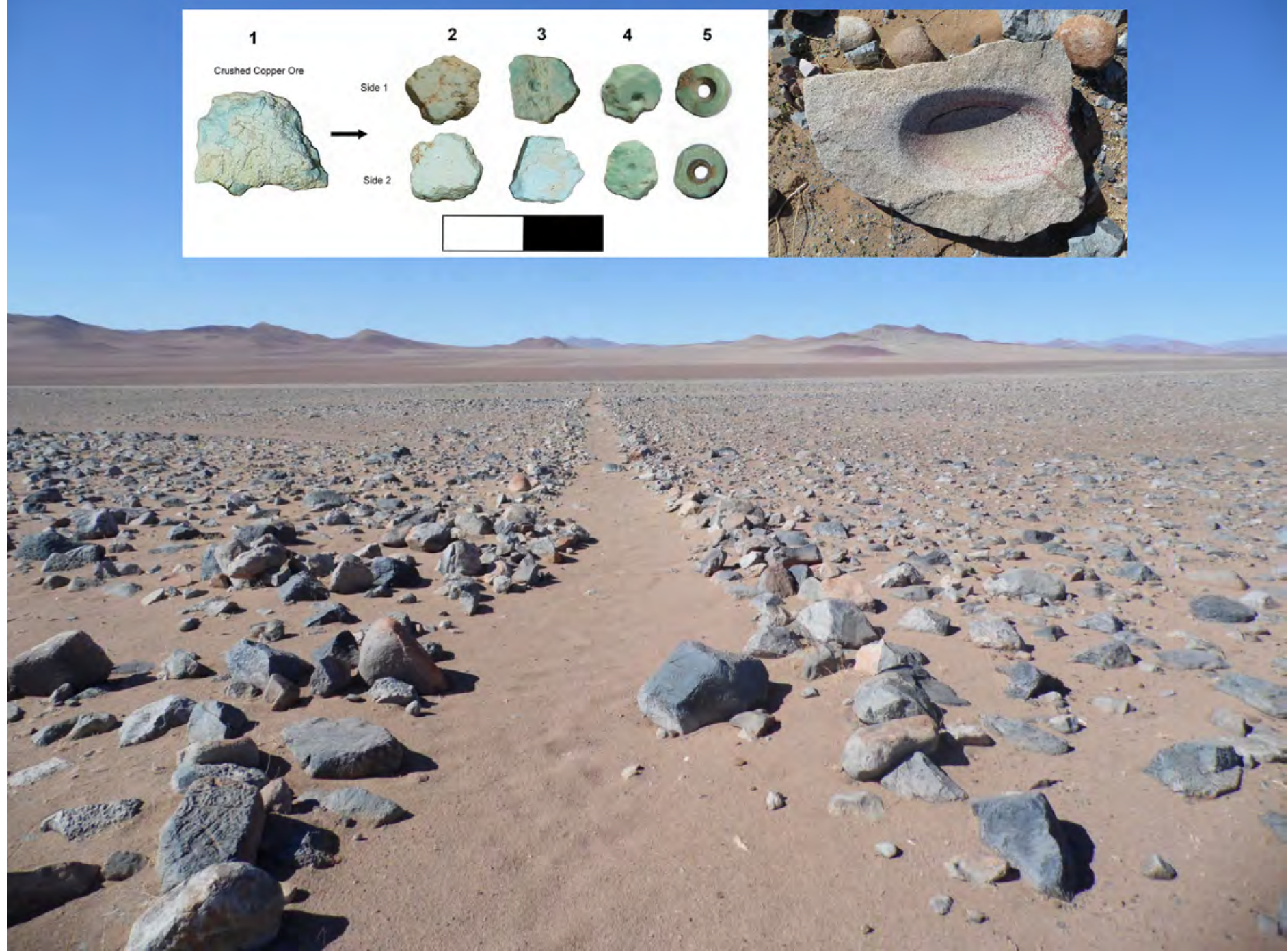